\title{
The next chapter for group B meningococcal vaccines
}

NY Wang ${ }^{1,2}$, AJ Pollard ${ }^{2,3}$

${ }^{1}$ Monash University, Melbourne, Australia, ${ }^{2}$ Oxford Vaccine Group, Department of

Paediatrics, ${ }^{3}$ University of Oxford and the NIHR Oxford Biomedical Research

Centre, Oxford, UK

\section{Author information:}

Nelson Y Wang (corresponding author)

Email: nywan3@student.monash.edu

ORCiD: 0000-0002-2538-6072

Address: 128/120 Sturt St, Southbank, Victoria, Australia 3006

Tel: +61(0)403 735786

Andrew J Pollard

Email: andrew.pollard@paediatrics.ox.ac.uk

Address: Oxford Vaccine Group, CCVTM, Churchill Hospital, Oxford, United Kingdom OX3 7LE

Tel: +44 (0)1865 234226/611313 


\title{
The next chapter for group B meningococcal vaccines
}

\author{
Abstract \\ The majority of invasive meningococcal disease (IMD) in the developed world is \\ caused by capsular group B Neisseria meningitidis, however success with vaccination \\ against organisms bearing this capsule has previously been restricted to control of \\ geographically limited clonal outbreaks. As we enter a new era, with the first routine \\ programme underway to control endemic group B meningococcal disease for infants in \\ the UK, it is timely to review the key landmarks in group B vaccine development, and \\ discuss the issues determining whether control of endemic group B disease will be \\ achieved. Evidence of a reduction in carriage acquisition of invasive group $\mathrm{B}$ \\ meningococcal strains, after vaccination among adolescents, is imperative if routine \\ immunisation is to drive population control of disease beyond those who are vaccinated \\ (i.e. through herd immunity). The need for multiple doses to generate a sufficiently \\ protective response and reactogenicity remain significant problems with the new \\ generation of vaccines. Despite these limitations, early data from the UK indicate that \\ new group B meningococcal vaccines have the potential to have a major impact on \\ meningococcal disease, and to provide new insight into how we might do better in the \\ future.
}

\section{Key Words}

Neisseria meningitidis, meningococcal disease, outer membrane vesicle, recombinant protein, factor $\mathrm{H}$ binding protein 


\section{Table of contents}

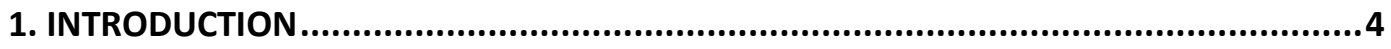

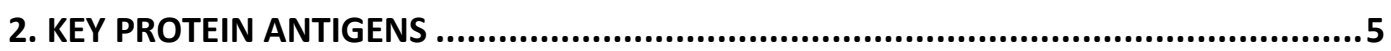

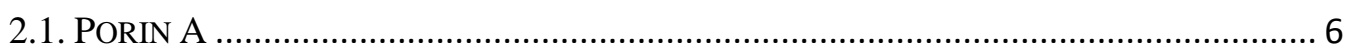

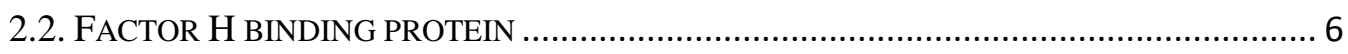

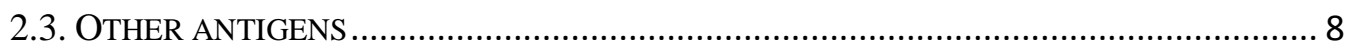

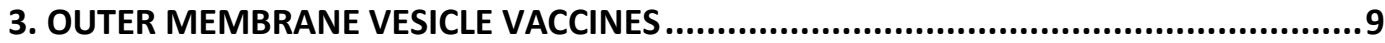

3.1. A SUMMARY OF DETERGENT EXTRACTED OMV VACCINES ................................ 10

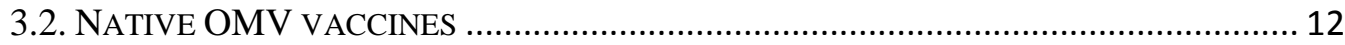

4. A RECOMBINANT-PROTEIN GROUP B MENINGOCOCCAL VACCINE .........................13

5. A MULTI-COMPONENT GROUP B MENINGOCOCCAL VACCINE .............................15

5.1. THE FIRST EXAMPLE OF ROUTINE INFANT IMMUNISATION AGAINST MENB.......... 16

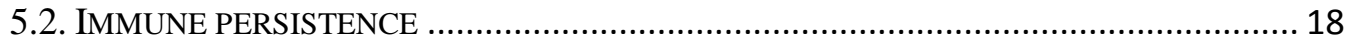

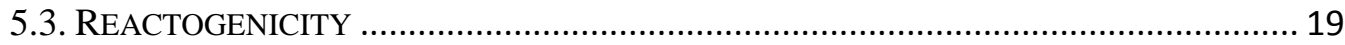

6. IMPACTING CARRIAGE ACQUISITION AND GENERATING HERD IMMUNITY ............20

7. ASSAYS TO PREDICT COVERAGE AND INFER PROTECTION ...................................21

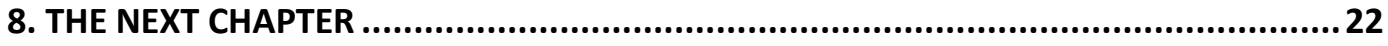

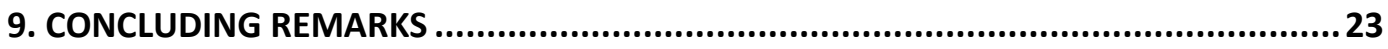

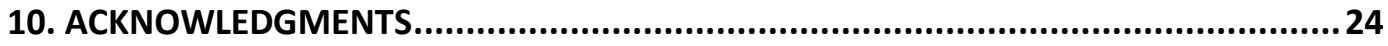

11. DECLARATIONS OF INTEREST ............................................................................24

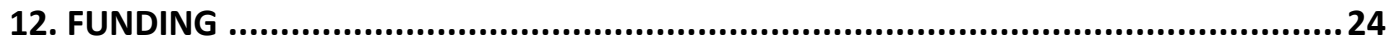

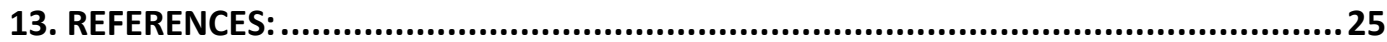




\section{Introduction}

Neisseria meningitidis (meningococcus) is an encapsulated Gram-negative bacterial pathogen responsible for significant morbidity and mortality worldwide by causing invasive meningococcal disease (IMD), most commonly manifesting as meningitis and septicemia (Jafri et al. 2013). The incidence of IMD follows a bi-modal distribution, with distinct peaks in the first year of life and in adolescence, due to immunological immaturity and increased carriage respectively (Jafri et al. 2013).

Vaccination is important for controlling $N$. meningitidis because of the rapid development of serious disease and the potential to generate herd immunity (van Deuren et al. 2000). Of the 12 capsular groups identified, A, B, C, W, X and Y are responsible for the majority of pathology through both endemic disease and outbreaks (Jafri et al. 2013). Unlike capsular groups A, C, W and Y, however, group B vaccines based on polysaccharide antigens are poorly immunogenic and even have the potential for auto-immunity in humans, since the sugars in the capsule also decorate human fetal neural tissues (Griffiss et al. 1981; Finne et al. 1983; Bruge et al. 2004; Trotter et al. 2005). Therefore, capsular group B N. meningitidis (MenB) is the dominant cause of meningococcal disease in Europe and America, as well as in several other regions (Harrison et al. 2009; Jafri et al. 2013).

In order to assess vaccine immunogenicity, human-serum bactericidal assays (hSBA), which measure levels of functional antibody, are the accepted correlate of protection. This is important for vaccine development in view of the relatively low incidence of IMD which renders formal efficacy assessment in the field logistically challenging (Bjune et al. 1991; Sierra et al. 1991; van Alphen \& van den Dobbelsteen 2008). An 
hSBA titre of $\geq 1: 4$ is considered a protective bactericidal response and has been accepted internationally (van Alphen \& van den Dobbelsteen 2008; Frasch et al. 2009).

Past and current group B meningococcal vaccines contain protein antigens expressed on the bacterial outer membrane which have been incorporated using three main approaches. Outer membrane vesicles (OMVs) derived from pathogenic strains have been used successfully as vaccines in the context of outbreaks caused by a single clonal isolate (Sierra et al. 1991; Oster et al. 2005). Another approach incorporates recombinant protein antigens in addition to an OMV to increase the breadth of protection induced, and has been used in outbreaks and in the context of endemic disease (Giuliani et al. 2006). Finally, a vaccine has been developed which includes two variants of a single meningococcal outer membrane protein (OMP) which has also shown cross-strain protection (Jiang et al. 2010). However, the antigenic variability of OMPs through mutation, recombination and phase variable expression leads to the potential for the pathogen to evade natural and induced immune responses (Tauseef et al. 2013). As a result, the development of a vaccine suitable for routine immunisation against endemic disease has been difficult (Shea 2013).

\section{Key protein antigens}

Group B meningococcal proteins have been identified through traditional biochemical protein purification (Fletcher et al. 2004) as well as through mining whole genome sequences, otherwise known as “reverse vaccinology” (Rappuoli \& Covacci 2003). Though reverse vaccinology is sensitive for identifying potentially useful meningococcal proteins, important candidates can be overlooked if prioritization is based on weak correlates of protection, such as ELISA titres (Pizza et al. 2000). Several 
key targets have been identified, though not all are suitable for use in a universal vaccine.

\subsection{Porin A}

Porin A (PorA) is a key outer membrane protein, with a strong link between PorA specific antibodies and bactericidal activity (Tappero et al. 1999; Martin et al. 2006). It also dictates the majority of the immune response induced by outer membrane vesicle vaccines, discussed in more detail below (Holst et al. 2009). However, PorA varies significantly between strains due to the presence of two extremely variable regions (VR1 and VR2) at the apices of two surface-exposed protein loops (van der Ley et al. 1991). Classification of PorA subtypes is based on these two regions and is expressed as 'P1.X' (Russell et al. 2004). Therefore, though capable of inducing strong bactericidal responses, PorA specific antibodies have limited cross reactivity and the protection conferred is largely limited to homologous strains (Granoff 2010).

\subsection{Factor $\mathrm{H}$ binding protein}

Factor $\mathrm{H}$ binding protein (fHbp), first identified through protein purification from other soluble OMPs, is also referred to as genetically-derived neisserial antigen 1870 (GNA1870) or LP2086 and aids in bacterial survival through binding factor $\mathrm{H}$ and down-regulating the host complement pathway (McNeil et al. 2013). Based on amino acid sequence fHbp is classified into subfamilies: group A, also classified as v.2 and v.3, and group B, corresponding to v.1 (Masignani et al. 2003). Significant crossreactivity is observed within subfamilies, but little cross-reactivity is observed between (Murphy et al. 2009). Lipidation of the N-terminus is believed to increase antigen exposure to the immune system through influencing its orientation when delivered as part of a vaccine (Mascioni et al. 2010). Two currently licensed vaccines contain fHbp, 
rLP2086 contains two lipidated fHbp subvariants, fHbp 3.45 from group A and fHbp 1.55 from group B (Jiang et al. 2010) whereas 4CMenB contains a non-lipidated fHbp 1.1, both discussed in more detail below (Giuliani et al. 2006). An important study found that more phylogenetically central fHbp subvariants are able to elicit protective antibodies with broader cross-strain bactericidal activity, though the use of some variants is limited by their stability when produced through recombinant protein expression (Konar et al. 2013; Konar et al. 2015). MenB strains which do not express fHbp, that are still capable of causing invasive disease, have been previously isolated (Lucidarme et al. 2011). Although these comprise a very small percentage of all invasive strains, vaccines which include only fHbp pose the risk of selecting for variants with low expression, either through mutation or phase variation (Lucidarme et al. 2011; Shea 2013).

Transient IgM autoantibodies to human factor $\mathrm{H}(\mathrm{fH})$ have been observed in some transgenic mice after vaccination with fHbp containing vaccines (Costa et al. 2014). Although IgG autoantibodies against human $\mathrm{fH}$ are associated with several rheumatological conditions (Foltyn Zadura et al. 2012), the significance of IgM autoantibodies in the aforementioned animal studies is currently unknown (Costa et al. 2014). No vaccine-related autoimmune reactions have been observed in humans after extensive safety trials (Costa et al. 2014), nor is there any evidence of survivors of. IMD contracting autoimmune disease as a result of fHbp expression during infection. The binding of fHbp to $\mathrm{fH}$ in recombinant protein vaccines has been shown to potentially reduce immunogenicity in transgenic mice and more recently in primates (Beernink et al. 2011). Gonococcal fHbp homologues (Jongerius et al. 2013) and nonfH binding fHbp mutants (Beernink et al. 2011) have been proposed as alternatives to circumvent the effect of human $\mathrm{fH}$ binding. There is preclinical evidence, for non- 
lipidated fHbp vaccines, that non-fH binding fHbp mutants can enhance immunogenicity compared with the corresponding wild type subvariant (Rossi et al. 2016). However there have been no studies directly comparing these non-lipidated mutants with non-mutated, lipidated fHbp subvariants. Determining the significance of human $\mathrm{fH}$ binding and whether anti-fH autoantibodies are present following immunization with 4CMenB or rLP2086 in humans is of importance.

\subsection{Other antigens}

Neisseria adhesin A (NadA) is a molecule involved in bacterial adhesion and penetration into epithelium (Capecchi et al. 2005) and was identified through reverse vaccinology (Serruto et al. 2012). However, though initially believed to be an important meningococcal virulence factor (Comanducci et al. 2004), more recent surveillance studies have found NadA to be absent from many MenB isolates (Lucidarme et al. 2009; Lucidarme et al. 2010) with Bambini et al. identifying NadA expression in only $30 \%$ of 165 isolates (Bambini et al. 2013). NadA comprises one of the four major antigens in the currently licensed vaccine 4CMenB (Giuliani et al. 2006).

Neisseria heparin binding antigen (NHBA), another antigen identified by reverse vaccinology included in 4CMenB (Serruto et al. 2012), also helps facilitate the adherence of meningococci to host epithelial cells (Vacca et al. 2016) and enables the pathogen to bind human heparin, associated with increased resistance to serum bactericidal activity (Serruto et al. 2010). Although NHBA was found to be consistently expressed across isolates in the same surveillance study, it was not expressed by many strains isolated from a recent outbreak in a large indigenous Irish Traveler family (Mulhall et al. 2016). Although it has been shown that in some instances NHBA is capable of inducing bactericidal activity in the absence of other vaccine antigens 
(Giuliani et al. 2006; Serruto et al. 2010), there is contrasting evidence that antibodies induced against NHBA by 4CMenB have a limited contribution to overall bactericidal activity when compared with its other components even against strains with homologous NHBA subtype (Partridge et al. 2016).

A number of other outer membrane proteins also have the potential to induce protective antibody responses as vaccine candidates and have been trialed in developmental vaccines including ferric enterobactin receptor A (FetA) (Urwin et al. 2004) and opacity protein A (OpcA) (Cantini et al. 2006). FetA exhibits a similar pattern of variation to PorA between strains, (Urwin et al. 2004) and the surface-exposed mobile loops of OpcA bearing the key epitopes are also highly variable, thus limiting cross-reactivity of these antigens (Cantini et al. 2006).

\section{Outer membrane vesicle vaccines}

Outer membrane vesicle (OMV) vaccines are derived directly from group B meningococcal strains, which produce blebs of outer membrane during normal liquid culture, and contain lipopolysaccharide (LPS) as well as outer membrane proteins embedded in the phospholipid bilayer (Bjune et al. 1991; Sierra et al. 1991; Oster et al. 2005). In addition to PorA, the immunodominant component of OMVs (Saukkonen et al. 1989), lipopolysaccharide (LPS) and FetA are also immunogenic (Ala'Aldeen et al. 1994; Arigita et al. 2005). Due to a high level of toxicity, all widely administered OMV vaccines are created through a detergent extraction process (dOMV) to reduce LPS content (also resulting in the loss of other detergent-soluble membrane constituents), leaving approximately $1 \%$ to maintain vesicle structure, see Fig. 1 (Williams et al. 2007; van de Waterbeemd et al. 2010). OMV vaccines are often also adsorbed to an 
aluminium adjuvant to enhance immunogenicity and minimize the toxicity associated with higher vaccine doses (Bjune et al. 1991; Sierra et al. 1991). As PorA, exhibits significant heterogeneity, variability and phase variation, dOMV vaccines are poorly cross-protective and would likely select for escape variants with routine immunisation (Urwin et al. 2004; Tauseef et al. 2013). Therefore, the successful use of dOMV vaccines which are not supplemented by additional recombinant proteins has, for the most part, been limited to the control of clonal outbreaks (Urwin et al. 2004).

\subsection{A summary of detergent extracted OMV vaccines}

The first two MenB dOMV vaccines to be widely deployed, VA-MENGOC-BC ${ }^{\mathrm{R}}$ (Institute of Finlay) and MenBvac ${ }^{\mathrm{R}}$ (National Institute of Public Health), were isolated from the dominant strain of the Cuban and Norwegian epidemics, respectively (Bjune et al. 1991; Sierra et al. 1991). VA-MENGOC-BC ${ }^{\mathrm{R}}$ was able to successfully protect adolescents and control the Cuban epidemic (Sierra et al. 1991), though exhibited poor immunogenicity in young children when used during an epidemic in Sao Paulo, Brazil (Table 1) despite homology of PorA subtype (de Moraes et al. 1992). As the vaccine was significantly more immunogenic in older Brazilian children, it is believed that younger subjects had not yet experienced the environmental $N$. meningitidis exposure necessary to prime a protective response (Granoff 2010). The extended follow up period of 29 months for the investigation of $\mathrm{MenBvac}^{\mathrm{R}}$ (Bjune et al. 1991) compared with other OMV vaccine studies (Sierra et al. 1991) lead to an estimation of only 57\% protection after two doses, likely due to poor immune persistence. At 10 months postvaccination, protection was estimated at $87 \%$ (Holst et al. 2003) and hence the vaccine was later used successfully during an epidemic in Normandy, France, with two initial doses and a booster dose at 10 months, see Table 1 (Caron et al. 2011). Both vaccines induced some cross-protection in older children against a Chilean epidemic strain 
expressing a heterologous PorA subtype (Table 1), eluding to the importance of nonPorA components retained after detergent extraction (de Moraes et al. 1992; Tappero et al. 1999). Antibodies targeting these proteins exhibit synergistic and additive effects important for protection (Sacchi et al. 2001; Weynants et al. 2007). However, once again the dOMV vaccines failed to induce a cross-protective responses in infants, even after 3 doses (Tappero et al. 1999).

In an attempt to combat the difficulty in inducing adequate cross-protection with dOMVs, hexavalent (HexaMen) and nonavalent (NonaMen) iterations, containing six and nine PorA variants respectively, have been trialed (Cartwright et al. 1999; van der Ley \& van den Dobbelsteen 2011). However, as PorA is still the immunodominant antigen and highly variable between strains, every additional subvariant would only offer significant protection against corresponding homologous strains (van der Ley et al. 1995; Cartwright et al. 1999). Even minor mutations in vaccine strains could diminish the vaccine's bactericidal activity and thus it may select for these variants with long term use (Tettelin et al. 2000; Martin et al. 2000). Multivalent dOMV vaccines were never deployed for large scale use and it has been estimated that theoretically, at least 20 separate PorA subtypes would have been required to cover $80 \%$ of the endemic MenB strains in the USA between 1992 and 1998, highlighting the limitations of this concept (Tondella et al. 2000).

MenZB $^{\mathrm{R}}$ (Novartis Vaccines) exhibited immunogenicity in clinical trials between 2001 and 2003 (Table 1) and was deployed in 2004 to control the New Zealand epidemic (Oster et al. 2005). MeNZB ${ }^{\mathrm{R}}$ was derived from strain NZ98/254 (B:4:P1.7) responsible for 86\% of all cases during an epidemic which began in 1991 and peaked in 2001 (Sexton et al. 2004; Oster et al. 2005). It is also the OMV included as a part of 4CMenB 
(Giuliani et al. 2006). Epidemiological analyses estimated 77\% effectiveness after three doses of MenZB ${ }^{\mathrm{R}}$ despite rapid waning of immunity as was observed with previous dOMV vaccines (Oster et al. 2005; Arnold et al. 2011).

The experience of developing and testing dOMV MenB vaccines provides important understanding which will direct the next steps in the control of endemic group B disease. The potential for environmental $N$. meningitidis exposure to prime and enhance vaccine responses, observed in Brazil and Chile, infers that asymptomatic carriage of nonvirulent strains might enhance protection. Non-PorA constituents of the outer membrane are important for cross-protection, however the immunodominance of PorA impinges on the cross-protective abilities of current dOMVs, particularly in young children. A developmental dOMV vaccine (MenPF-1) with constitutive expression of FetA can induce specific bactericidal responses directed against both FetA and PorA which could broaden the range of strains covered by the vaccine, though is unlikely to be universal as FetA is also subject to phase and strain variation (Sanders et al. 2015; Marsay et al. 2015). Cross-protection against other neisserial pathogens, such as Neisseria gonorrhoeae, may be an important additional gain from vaccination against MenB as it has a bearing on potential health and health economic impacts of MenB vaccines. While, achieving broad protection against gonorrhea with a dOMV vaccination is likely to be difficult, due to high levels of antigenic variation between $N$. gonorrhoeae strains, some evidence exists that such an effect may be possible with MenZB $^{\mathrm{R}}$ in New Zealand (Petousis-Harris et al. 2016; Edwards et al. 2016). Confirmation and further evaluation of the nature of such cross-protective responses may also provide insight into the development of a dedicated $N$. gonorrhoeae vaccine.

\subsection{Native OMV vaccines}


The Lipid A portion of LPS is responsible for its endotoxin activity warranting the detergent extraction process for OMV vaccines (Rietschel et al. 1990). Deletion of a key gene in the synthesis of Lipid A (LpxL1) attenuates endotoxin activity in vitro and has the potential to render detergent-free OMV vaccines safe for humans (Fisseha et al. 2005). These "native” OMV (nOMV) vaccines conserve non-PorA outer membrane proteins (OMPs) normally lost in the detergent extraction process and show enhanced cross-protection through SBA when compared with dOMVs (Fisseha et al. 2005). A multivalent nOMV vaccine containing an fHbp variant, two PorA variants and OpcA, was found in phase I trials to have an acceptable reactogenicity profile, though increases in leukocytes and temperature indicated residual endotoxin activity (Keiser et al. 2011). There was evidence that the immune response induced was greater against a PorA heterologous strain than against the parent strain, suggesting that nOMVs are less PorAdominant, and thus they have the potential for enhanced cross-protection (Keiser et al. 2011). A recent developmental nOMV vaccine (NOMV-FHbp) has shown broader bactericidal coverage against heterologous fHbp subvariants than the currently licensed multicomponent vaccine $4 \mathrm{CMenB}$ in transgenic mice, though this may be aided by the inclusion of a non-factor H binding fHbp mutant (Pajon et al. 2016).

The genetically detoxified nOMV concept may improve cross-protection and immunogenicity as an alternative to dOMV. Improvements in production yields without structural compromise have also been achieved and large scale production of nOMV is a possibility (van de Waterbeemd et al. 2013; Maharjan et al. 2016). However, further human trials are necessary to clarify their residual endotoxicity as dOMVs are already considered significantly reactogenic (Holst et al. 2009; Prymula et al. 2014).

\section{A recombinant-protein group $B$ meningococcal vaccine}


The bivalent fHbp based vaccine, rLP2086 (TruMenba ${ }^{\mathrm{R}}$, Pfizer), contains lipidated fHbp from both subfamilies (A05 and B01 or using alternative nomenclature, fHbp 3.45 and fHbp 1.55) as a means of achieving wider cross-protection (Jiang et al. 2010). Recently, characterization of the lipidation of fHbp as part of rLP2086 has shown that it alters the delivery of the antigen to the immune system, positioning the antigen as a micelle-like complex more similar to antigen presentation during MenB infection, as well as acting as an adjuvant (Luo et al. 2016). Initial pre-clinical studies showed protective SBA responses against MenB strains expressing fHbp from both family A and B though strains with minimal fHbp expression were not covered (Jiang et al. 2010). Safety and immunogenicity were established in phase II/III trials (Table 2), even with other scheduled vaccinations (Richmond et al. 2012; Marshall et al. 2013; Nissen et al. 2013; Vesikari et al. 2016). It is currently licensed for 10-25 year olds and has a category B recommendation for use in 16-23 year olds for short-term protection against most strains of MenB (CDCP 2015). As of February 2015, rLP2086 also has a category A recommendation for administration to all "high risk" adolescents and adults as a three dose schedule in the US (CDCP 2015). Due to the need for accelerated approval, the Food and Drug Association (FDA) licensed rLP2086 under the condition that postmarketing confirmation of efficacy and safety with further research would be conducted (Smith 2016). This was fulfilled and rLP2086 was granted traditional approval on the $13^{\text {th }}$ of March 2017 in the US (Sun 2017). Reactogenic events are largely limited to localized reactions in adolescent trials, with very few examples of a systemic reaction such as fever or headache attributed to the vaccine compared with controls groups (Marshall et al. 2013; Ostergaard et al. 2016). Though there are limited studies, rLP2086 also appears to be well tolerated in younger children, with paucity of significant adverse effects and only $4 \%$ of toddlers aged 18 to 36 months developing 
fever after vaccination (Marshall et al. 2012). Data in a phase II follow-on trial shows the potential for significant immune persistence as $>50 \%$ of vaccinees still had protective bactericidal antibody titres 4 years after vaccination, although anamnestic responses were not investigated (Marshall, Richmond, et al. 2016). Recently rLP2086 was used as part of a rapid response to control an outbreak among university students in Rhode Island, United States where 3525 students were vaccinated in total and no cases were observed after vaccination (Fiorito et al. 2015).

The inclusion of only one antigen family raises concerns regarding the selection for escape variants with ultra-low fHbp expression if the vaccine is ever to be recommended routinely (Zlotnick et al. 2015; Ostergaard et al. 2016; Vesikari et al. 2016). If rLP2086 is to be administered to entire adolescent cohorts, a population with high rates of carriage, monitoring of any real global effect of selection pressures induced by vaccination and its effect on carriage acquisition should be undertaken.

\section{A multi-component group B meningococcal vaccine}

4CMenB (Bexsero $^{\mathrm{R}}$, GSK) is comprised of four main components (Fig. 2). Factor $\mathrm{H}$ binding protein (fHbp 1.1), Neisseria heparin binding antigen (NHBA) and Neisseria adhesin A (NadA) are included as recombinant proteins, supplementing a dOMV based on the New Zealand outbreak strain NZ98/254 (B:4:P1.7-2,4) (Giuliani et al. 2006). Through a series of phase I, II and III trials (Table 3), 4CMenB exhibited both safety and induction of cross-protective responses in adults and infants (Snape et al. 2010; Findlow et al. 2010; Kimura et al. 2011; Toneatto et al. 2011; Gossger et al. 2012; Vesikari et al. 2013). 4CMenB is now licensed in 37 countries, either for those aged 2 months and above, such as in Europe, Canada and Australia (Canada Public Health 
Division 2014; ATAGI 2015; EMA 2015), or for adolescents and adults, such as in the United States (CDCP 2015). Just as with rLP2086, 4CMenB currently has a category B recommendation for 16-23 year olds and category A for all "high risk" individuals, and for outbreak control, as a two dose schedule (CDCP 2015) and also requires further, post-marketing evidence of efficacy in order to maintain its FDA license, obtained via accelerated approval (Gruber 2015). The European Medicines Agency (EMA) also requested the submission of periodic safety reports for the vaccine as a part of its approval, with additional monitoring for adverse events (EMA 2012). At this stage the United Kingdom is the only country to have incorporated 4CMenB as a part of the routine vaccine schedule for infants (Ladhani et al. 2016). 4CMenB was deployed prior to licensure in the US as a two-dose regime in response to epidemics occurring at two universities (Basta et al. 2016). In Quebec, Canada, the vaccine was given to patients of ages outside the original license during an epidemic in 2014 (De Wals 2015). Vaccination in the US was temporally linked with cessation of the epidemics, and only 3 cases of IMD have been reported since vaccination in Quebec, all of which were in unvaccinated individuals (De Wals 2015; Basta et al. 2016). Although administration of $4 \mathrm{CMenB}$ as a two dose schedule is the current recommendation, supported by evidence that an additional dose in adolescents does not provide additional protection when measured at 1 month after each dose (Santolaya et al. 2012), only 66.1\% of vaccinees were found to be protected against a US university outbreak strain at 2 months after two doses (Basta et al. 2016). This suggests that whilst an additional dose does not enhance protection at 1 month post-vaccination, it may enhance persistence of the response. Further research with a longer duration of follow up is needed to clarify the effect of an additional dose on immune persistence in adolescents.

\subsection{The first example of routine infant immunisation against MenB}


In September 2015, the United Kingdom (UK) became the first country to incorporate 4CMenB into its regular infant schedule after extensive negotiations, see Fig. 3 (JCVI 2014). The decision was based on safety, immunogenicity, predicted coverage (73-88\% of pathogenic strains in the UK) and the high mortality rate of IMD (Frosi et al. 2013; Vogel et al. 2013; Christensen et al. 2014; Ladhani et al. 2016). Although initially the Joint Committee on Vaccination and Immunisation (JCVI) found that 4CMenB's inclusion in the routine infant immunisation schedule would not prove cost-effective at any price (defined as $<£ 20,000$ per quality adjusted life-year gained), the availability of additional data following consultation lead to a re-evaluation (Christensen et al. 2014). The JCVI reduced schedule of doses given at 2, 4 and 12 months of age was deemed cost-effective, depending on the use of favorable or conservative parameters, between $£ 7$ and $£ 22$ per dose (Christensen et al. 2014). A routine adolescent programme could not be justified, even though this might be the optimal approach, without largescale data showing the impact of $4 \mathrm{CMenB}$ on reducing carriage acquisition (Christensen et al. 2014). Analyses of the cost-effectiveness of a routine infant schedule have been undertaken in other countries, though no other programmes have been deemed sufficiently cost effective for recommendation thus far (Pouwels et al. 2013; Tirani et al. 2015; Christensen et al. 2016; Gasparini et al. 2016).

4CMenB was offered to all infants in England born after the $1^{\text {st }}$ of July 2015, as well as catch-up doses for infants born in May and June of 2015 (Public Health England 2015). Vaccine coverage was high and did not decrease dramatically between the first and second dose despite the propensity for $4 \mathrm{CMenB}$ to cause adverse reactions, see Fig. 4a (Parikh et al. 2016). Due to a downward trend in infant case rates prior to rolling out 4CMenB, a Poisson regression model was used when calculating vaccine impact to correct for potential bias (Parikh et al. 2016). A total of 37 group B IMD cases were 
identified between September 2015 and June 2016 after initiation of the program (Fig. 4b), a $42 \%$ case reduction compared with the predicted case number for this time period

(58 cases) based on the trend established in the prior 4 years (Parikh et al. 2016). According to data from the cohort study (Fig. 4c), the effectiveness of 4CMenB was estimated at $83 \%$ against all MenB in the UK after two doses (95\% CI 24·1-95·2) and $22 \%$ after one dose $(95 \% \mathrm{CI}-105-67 \cdot 1)$ (Parikh et al. 2016). The preliminary evidence of the impact and effectiveness after two doses are promising, though it is apparent that infants are still vulnerable after the first dose (Parikh et al. 2016). A vaccine with greater immunogenicity and protection after a single dose is required if infants $\leq 4-5$ months of age are to be protected. Alternatively, maternal immunization would potentially protect infants of this age (Chu \& Englund 2014), however infant vaccination would still be required to ensure persistence through the first disease peak and thus this regime is unlikely to be cost effective.

\subsection{Immune persistence}

Immune persistence could have significant bearing on the suitability of $4 \mathrm{CMenB}$ as a routine vaccine, particularly if administered in infancy without later boosters, as protection should last throughout the infant and adolescent peaks. Boosting at 12 months with 4CMenB has been shown to improve bactericidal responses and may help immunity persist through the first disease peak, to approximately 24 months of age (Carter 2013; Snape et al. 2016). The administration of an additional dose at 40-44 months of age, to toddlers who had previously completed the infant schedule, showed an anamnestic response as waning immunity was able to be boosted again (Snape et al. 2013). This important observation may impact the approach to adolescent vaccination in the future. After the first 2 years of life, disease rates decline dramatically and further boosters at this age will not significantly impact the burden of endemic disease (Jafri et 
al. 2013). However, if the induced immunological memory after doses at 2, 4 and 12 months of age is sufficient, another boost delivered in early adolescence, prior to rising disease rates, may provide additional protection (Jafri et al. 2013). This would lower the cost of adolescent coverage compared with a dedicated adolescent immunisation programme. Immune persistence after a two dose schedule in adolescents appears to be more robust than in early childhood (Santolaya et al. 2012).

\subsection{Reactogenicity}

Although considered safe, vaccine induced reactions are commonly observed when administering 4CMenB in both adolescents (Santolaya et al. 2012) and infants (Carter 2013). Pain at the injection site was prominent among adolescent and adult vaccinees during a phase IIb/III trial (Santolaya et al. 2012). However, in addition to mild adverse effects such as injection-site tenderness and erythema, fever $>38.5^{\circ} \mathrm{C}$ was observed in $65.3 \%$ of infants who received $4 \mathrm{CMenB}$ with their regular immunizations in a phase III trial (Carter 2013; Prymula et al. 2014). These children benefitted from prophylactic paracetamol provided with immunisation (Carter 2013). There is difficulty in differentiating significant temperature rises in the days after receiving 4CMenB from other pathology and there are data available showing a clinically significant number of infant presentations due to "probable" or "possible" $4 \mathrm{CMenB}$ induced reactions at a tertiary UK hospital in the year after its recommendation (Nainani et al. 2016). Although the reactogenicity of $4 \mathrm{CMenB}$ is outweighed by protection conferred, the healthcare costs of hospital admissions are marked and thus should be taken into account as vaccine related hospital presentations continue in the long term (Jones 2011). Vaccine reactogenicity also plays a role in public attitudes towards adopting and complying with meningococcal immunisation campaigns (Marshall et al. 2016). 


\section{Impacting carriage acquisition and generating herd}

\section{immunity}

Establishing herd immunity contributes significantly towards controlling disease caused by encapsulated bacteria through vaccination and a large proportion of the success of the MenC vaccine is attributed to this (Trotter \& Maiden 2009; Read et al. 2014). Adolescents acquire meningococcal carriage at a high rate due to social behavior (MacLennan et al. 2006) and are predominantly responsible for transmission of meningococci, between themselves and to other susceptible age groups (Vetter et al. 2016). Therefore this cohort must be targeted by vaccination in early adolescence prior to the peak period of carriage acquisition if herd immunity is to be achieved (Jeppesen et al. 2015). At this stage little is known regarding the impact of current licensed MenB vaccines on carriage acquisition and transmission among adolescents. There is some evidence that rLP2086 does not impact meningococcal carriage, though this was based on data collected after only one dose (Soeter et al. 2015). A study has shown that 4CMenB reduces carriage of meningococci as a whole but is inconclusive about the effect on MenB specifically (Read et al. 2014) and it is important to note the report of a case of MenB IMD in an unvaccinated subject after contact with a vaccinated student present during a US university outbreak (CDCP 2014). The assessment of an impact on herd immunity with MenB immunisation is complex and an absolute reduction in MenB carriage may not directly correlate with a reduction in acquiring disease. There are several factors involved such as the virulence of the strain affected, its interaction with the host and other host factors, perhaps including carriage density. It may be speculated that group B meningococcal vaccines are able to affect carriage acquisition of particularly virulent strains, corresponding to vaccine antigens, without evidence of a significant impact on MenB carriage as a whole, see Fig. 5 (Read et al. 2014). In this 
scenario, exposure to non-invasive Neisseria strains would continue to prime immune responses and herd immunity may be generated with vaccination of adolescent cohorts (de Moraes et al. 1992; Tappero et al. 1999; Vetter et al. 2016). Analyses may be possible through a case controlled study which is sufficiently powered to detect and identify differences in the carriage of specific MenB strains between vaccinated and non-vaccinated subjects. In this case, participants should be enrolled and vaccinated prior to the peak period of acquisition. Alternatively, investigation is also possible if the vaccine is routinely recommended for entire adolescent cohorts. Currently there are large scale studies planned in Australia (Marshall 2016) and the United Kingdom (Finn et al. 2016) which have the potential to provide valuable information regarding the effect of 4CMenB on carriage acquisition.

\section{Assays to predict coverage and infer protection}

The use of in vitro assays to predict the coverage of immune sera offers an alternative to the large serum requirements of extensive hSBA cross-protection panels, though the utility of these assays is not yet known (Nolan et al. 2015). The assays discussed in this section predict bactericidal coverage from laboratory analysis of immune serum, induced by vaccination, though are unable to predict the proportion of the vaccinated population who will respond to the immunisation and become protected. During the development of rLP2086, an assay was developed to predict vaccine coverage based on the principle that bactericidal activity is proportional to the total expression levels of fHbp, assessed through fluorescence-activated cell sorting (FACS) with an antibody that recognizes a region of fHbp conserved among all subvariants (Jiang et al. 2010; Harris et al. 2011). This assay is based on the assumption that vaccine-induced antibodies will be equally cross-protective against all fHbp subvariants. In contrast, the 
Meningococcal Antigen Typing System (MATS) is antigen specific. It was developed in conjunction with 4CMenB, and combines PorA genotyping with ELISA analyses to assess the level of expression and cross reactivity of antibodies (relative potency) induced against fHbp, NHBA and NadA subvariants found on various strains of MenB as a means of estimating protective coverage (Medini et al. 2015). A strain is considered as "covered" if it expresses homologous PorA, or if expression of another vaccine antigen meets the minimum threshold of reactivity based on ELISA. However, this method does not take into account the contribution of non-PorA OMV antigens, nor does it account for synergy between the components in 4CMenB, known to be affected by the position of vaccine antigens on the pathogen's outer membrane (Weynants et al. 2007). As such, it has been shown to underestimate actual coverage (Frosi et al. 2013). Both genotypic and phenotypic attributes may be used in future assays, combining assessment of antigen promoter sequences, antigen sequence distance from vaccine antigens, phase variation, and the position of antigens on the outer membrane in order to more accurately predict coverage and account for bactericidal synergy in future assays.

\section{The next chapter}

The next major question to be addressed is the potential impact of routine immunisation of adolescents against MenB. Only then can we improve our understanding of the effect of protein vaccines on the carriage of invasive MenB strains, necessary for herd immunity. Post vaccination surveillance methods, which have the ability to accurately identify strains with a known propensity for invasion during asymptomatic carriage, will be important to monitor this effect as well as guide further improvements. 
The cost of a long-term routine adolescent immunisation programme will be difficult to justify without already having obtained evidence of an impact on herd immunity. If routine infant vaccinees can be boosted with a single dose of MenB vaccine in early adolescence, and such a programme can induce herd immunity, the economic arguments for adolescent vaccination may be more favorable.

If we are to consider the next generation of capsular group B meningococcal vaccines, they should ideally be sufficiently immunogenic so that broad cross-protection is induced after just one dose in infancy and the carriage of disease causing strains is prevented with a booster in adolescence. Current vaccines require multiple doses to enhance cross-protective responses in infants, however the inclusion of a native OMV with LpxL1 mutation and overexpressed non-PorA OMPs, recombinant fHbp which does not bind human $\mathrm{fH}$, or more phylogenetically central antigen subvariants, may enhance immunogenicity and cross-protection. Vaccines will likely continue to involve multiple antigen families such that immunisation does not select for strains with low expression of any individual vaccine antigen or variant, though less reactogenic components may improve the acceptability of these vaccines.

\section{Concluding remarks}

Although several key epidemics have directed the development of group B meningococcal vaccines, the introduction of a routine infant immunisation program to control endemic disease in the United Kingdom marks the start of a new chapter. If the initial promising results are maintained, more widespread use of routine vaccination, where cases are prevalent, could reduce the burden of this deadly disease. Immunisation of adolescents could provide further benefits if herd immunity can be induced through 
the vaccination of cohorts of teenagers. However, the lack of universal protection, the risk of emergence of new clones that cannot be controlled by the current vaccines, and the reactogenicity associated with these products means that ongoing investment in the next generation of vaccines is a priority for the next chapter.

\section{Acknowledgments}

Some figures in this manuscript were produced using components from Servier Medical Art with permission, for which the authors would like to acknowledge Servier. Available from: http://www.servier.com/Powerpoint-image-bank

\section{Declarations of interest}

AJP has previously conducted clinical trials of vaccines on behalf of Oxford University funded by meningococcal vaccine manufacturers but does not receive any personal payments from them. His department received unrestricted educational grants from Pfizer/GSK/Astra Zeneca in July 2016 for a course on Infection and Immunity in Children.

AJP is chair of the UK Department of Health's (DH) Joint Committee on Vaccination and Immunisation (JCVI), and a member of WHOs SAGE, but the views expressed in this manuscript do not necessarily represent the views of JCVI or DH or WHO.

\section{Funding}

AJP is supported by the NIHR Oxford Biomedical Research Centre. 


\section{References:}

Ala'Aldeen DA, Davies HA, Borriello SP. 1994. Vaccine potential of meningococcal FrpB: studies on surface exposure and functional attributes of common epitopes. Vaccine [Internet]. [cited 2016 Nov 8]; 12:535-41. Available from: http://www.ncbi.nlm.nih.gov/pubmed/7518627

van Alphen L, van den Dobbelsteen G. 2008. Meningococcal B vaccine development and evaluation of efficacy. Hum Vaccin [Internet]. [cited 2016 Sep 4]; 4:158-61. Available from: http://www.ncbi.nlm.nih.gov/pubmed/18388494

Arigita C, Luijkx T, Jiskoot W, Poelen M, Hennink WE, Crommelin DJA, Ley P van der, Els C van, Kersten GFA. 2005. Well-defined and potent liposomal meningococcal B vaccines adjuvated with LPS derivatives. Vaccine [Internet]. [cited 2016 Aug 26]; 23:5091-5098. Available from: http://linkinghub.elsevier.com/retrieve/pii/S0264410X05005670

Arnold R, Galloway Y, McNicholas A, O’Hallahan J. 2011. Effectiveness of a vaccination programme for an epidemic of meningococcal B in New Zealand. Vaccine [Internet]. [cited 2016 Aug 26]; 29:7100-6. Available from: http://www.ncbi.nlm.nih.gov/pubmed/21803101

ATAGI. 2015. Australian Technical Advisory Group on Immunisation (ATAGI) Statement for Bexsero [Internet]. Canberra: Australian Government Department of Health; [cited 2015 Sep 10]. Available from:

http://www.immunise.health.gov.au/internet/immunise/publishing.nsf/Content/atagiadvice-bexsero

Bambini S, Piet J, Muzzi A, Keijzers W, Comandi S, De Tora L, Pizza M, Rappuoli R, van de Beek D, van der Ende A, et al. 2013. An Analysis of the Sequence Variability of Meningococcal fHbp, NadA and NHBA over a 50-Year Period in the Netherlands.Borrow R, editor. PLoS One [Internet]. [cited 2017 Jan 29]; 8:e65043. Available from: http://dx.plos.org/10.1371/journal.pone.0065043

Basta NE, Mahmoud AAF, Wolfson J, Ploss A, Heller BL, Hanna S, Johnsen P, Izzo R, Grenfell BT, Findlow J, et al. 2016. Immunogenicity of a Meningococcal B Vaccine during a University Outbreak. N Engl J Med [Internet]. [cited 2016 Aug 31]; 375:220-228. Available from: http://www.nejm.org/doi/10.1056/NEJMoa1514866

Beernink PT, Shaughnessy J, Braga EM, Liu Q, Rice PA, Ram S, Granoff DM. 2011. A meningococcal factor $\mathrm{H}$ binding protein mutant that eliminates factor $\mathrm{H}$ binding enhances protective antibody responses to vaccination. J Immunol [Internet]. [cited 2015 Sep 13]; 186:3606-14. Available from: http://www.jimmunol.org/cgi/doi/10.4049/jimmunol.1003470

Bjune G, Hiby E., Grnnesby J., Arnesen O, Fredriksen J., Lindbak A-K, Nkleby H, Rosenqvist E, Solberg L., Closs O, et al. 1991. Effect of outer membrane vesicle vaccine against group B meningococcal disease in Norway. Lancet [Internet]. [cited 2016 Aug 26]; 338:1093-1096. Available from: http://linkinghub.elsevier.com/retrieve/pii/014067369191961S 
Bruge J, Bouveret-Le Cam N, Danve B, Rougon G, Schulz D. 2004. Clinical evaluation of a group B meningococcal N-propionylated polysaccharide conjugate vaccine in adult, male volunteers. Vaccine [Internet]. [cited 2016 Aug 31]; 22:108796. Available from: http://www.ncbi.nlm.nih.gov/pubmed/15003635

Canada Public Health Division. 2014. Meningococcal B Vaccine (Bexsero ${ }^{\circledR}$ ): Q\&A for health care providers [Internet]. Ontario; [cited 2017 Jan 28]. Available from:

http://www.health.gov.on.ca/en/pro/programs/immunization/docs/meningococcal_b_h cp_qa_en.pdf

Cantini F, Savino S, Scarselli M, Masignani V, Pizza M, Romagnoli G, Swennen E, Veggi D, Banci L, Rappuoli R. 2006. Solution Structure of the Immunodominant Domain of Protective Antigen GNA1870 of Neisseria meningitidis. J Biol Chem [Internet]. [cited 2017 Jan 10]; 281:7220-7227. Available from:

http://www.ncbi.nlm.nih.gov/pubmed/16407174

Capecchi B, Adu-Bobie J, Di Marcello F, Ciucchi L, Masignani V, Taddei A, Rappuoli R, Pizza M, Aricò B. 2005. Neisseria meningitidis NadA is a new invasin which promotes bacterial adhesion to and penetration into human epithelial cells. Mol Microbiol [Internet]. [cited 2015 Sep 1]; 55:687-98. Available from:

http://www.scopus.com/inward/record.url?eid=2-s2.013444278985\&partnerID=tZOtx3y1

Caron F, du Châtelet IP, Leroy J-P, Ruckly C, Blanchard M, Bohic N, Massy N, Morer I, Floret D, Delbos V, et al. 2011. From tailor-made to ready-to-wear meningococcal B vaccines: longitudinal study of a clonal meningococcal B outbreak. Lancet Infect Dis [Internet]. [cited 2016 Aug 31]; 11:455-63. Available from: http://www.ncbi.nlm.nih.gov/pubmed/21489881

Carter NJ. 2013. Multicomponent meningococcal serogroup B vaccine (4CMenB; Bexsero $\left({ }^{\circledR}\right)$ ): a review of its use in primary and booster vaccination. BioDrugs [Internet]. [cited 2015 Apr 14]; 27:263-74. Available from:

http://www.ncbi.nlm.nih.gov/pubmed/23575646

Cartwright K, Morris R, Rümke H, Fox A, Borrow R, Begg N, Richmond P, Poolman J. 1999. Immunogenicity and reactogenicity in UK infants of a novel meningococcal vesicle vaccine containing multiple class 1 (PorA) outer membrane proteins. Vaccine [Internet]. [cited 2016 Aug 26]; 17:2612-9. Available from: http://www.ncbi.nlm.nih.gov/pubmed/10418910

CDCP. 2014. Meningococcal Disease Update. Centers Dis Control Prev [Internet]. Available from: https://www.cdc.gov/media/releases/2014/s0318meningococcal-diisease.html

CDCP. 2015. Use of Serogroup B Meningococcal Vaccines in Adolescents and Young Adults: Recommendations of the Advisory Committee on Immunization Practices, 2015. Centers Dis Control Prev [Internet]. Available from: http://www.cdc.gov/mmwr/preview/mmwrhtml/mm6441a3.htm

Christensen H, Irving T, Koch J, Trotter CL, Ultsch B, Weidemann F, Wichmann 
O, Hellenbrand W. 2016. Epidemiological impact and cost-effectiveness of universal vaccination with Bexsero ${ }^{\circledR}$ to reduce meningococcal group B disease in Germany. Vaccine [Internet]. [cited 2016 Nov 9]; 34:3412-3419. Available from: http://linkinghub.elsevier.com/retrieve/pii/S0264410X16301244

Christensen H, Trotter CL, Hickman M, Edmunds WJ. 2014. Re-evaluating cost effectiveness of universal meningitis vaccination (Bexsero) in England: modelling study. BMJ [Internet]. [cited 2016 Sep 5]; 349:g5725. Available from: http://www.ncbi.nlm.nih.gov/pubmed/25301037

Chu HY, Englund JA. 2014. Maternal immunization. Clin Infect Dis [Internet]. [cited 2017 Jan 12]; 59:560-8. Available from: http://www.ncbi.nlm.nih.gov/pubmed/24799324

Comanducci M, Bambini S, Caugant DA, Mora M, Brunelli B, Capecchi B, Ciucchi L, Rappuoli R, Pizza M. 2004. NadA diversity and carriage in Neisseria meningitidis. Infect Immun [Internet]. [cited 2015 Sep 1]; 72:4217-23. Available from:

http://www.pubmedcentral.nih.gov/articlerender.fcgi?artid=427459\&tool=pmcentrez \&rendertype $=$ abstract

Costa I, Pajon R, Granoff DM. 2014. Human factor H (FH) impairs protective meningococcal anti-FHbp antibody responses and the antibodies enhance FH binding. MBio [Internet]. [cited 2015 Aug 14]; 5:e01625-14. Available from: http://www.pubmedcentral.nih.gov/articlerender.fcgi?artid=4173785\&tool=pmcentrez \&rendertype=abstract

van Deuren M, Brandtzaeg P, van der Meer JW. 2000. Update on meningococcal disease with emphasis on pathogenesis and clinical management. Clin Microbiol Rev [Internet]. [cited 2016 Aug 30]; 13:144-66. Available from: http://www.ncbi.nlm.nih.gov/pubmed/10627495

Edwards JL, Jennings MP, Apicella MA, Seib KL. 2016. Is gonococcal disease preventable? The importance of understanding immunity and pathogenesis in vaccine development. Crit Rev Microbiol [Internet]. [cited 2016 Oct 18]; 42:928-941. Available from: https://www.tandfonline.com/doi/full/10.3109/1040841X.2015.1105782

EMA. 2012. Bexsero - EPAR public assessment report [Internet]. [place unknown]; [cited 2017 Mar 17]. Available from: http://www.ema.europa.eu/docs/en_GB/document_library/EPAR__Public_assessment_report/human/002333/WC500137883.pdf

EMA. 2015. EPAR summary for the public - Bexsero [Internet]. [place unknown]; [cited 2017 Jan 28]. Available from: http://www.ema.europa.eu/docs/en_GB/document_library/EPAR__Summary_for_the_public/human/002333/WC500137857.pdf

Findlow J, Borrow R, Snape MD, Dawson T, Holland A, John TM, Evans A, Telford KL, Ypma E, Toneatto D, et al. 2010. Multicenter, open-label, randomized phase II controlled trial of an investigational recombinant Meningococcal serogroup 
$B$ vaccine with and without outer membrane vesicles, administered in infancy. Clin Infect Dis [Internet]. [cited 2016 Aug 31]; 51:1127-37. Available from: http://www.ncbi.nlm.nih.gov/pubmed/20954968

Finn A, Trotter C, Christensen H, Oliver J. 2016. Study to evaluate prevention of meningococcal carriage in teenagers (SPIT) [Internet]. [cited 2017 Jan 29]. Available from: http://www.meningitis.org/current-projects/study-to-evaluate-prevention116650

Finne J, Leinonen M, Mäkelä PH. 1983. Antigenic similarities between brain components and bacteria causing meningitis. Implications for vaccine development and pathogenesis. Lancet (London, England) [Internet]. [cited 2016 Aug 31]; 2:3557. Available from: http://www.ncbi.nlm.nih.gov/pubmed/6135869

Fiorito T, Mihalakos A, Alexander-Scott N, Dennehy PH. 2015. Rapid Response to a Rhode Island College Outbreak of Meningococcal Serogroup B Disease: Nation's First Widespread use of Trumenba Vaccine. Open Forum Infect Dis [Internet]. [cited 2016 Oct 27]; 2:1873. Available from: https:/idsa.confex.com/idsa/2015/webprogram/Paper52760.html

Fisseha M, Chen P, Brandt B, Kijek T, Moran E, Zollinger W. 2005. Characterization of native outer membrane vesicles from lpxL mutant strains of Neisseria meningitidis for use in parenteral vaccination. Infect Immun [Internet]. [cited 2016 Oct 6]; 73:4070-80. Available from: http://www.ncbi.nlm.nih.gov/pubmed/15972495

Fletcher LD, Bernfield L, Barniak V, Farley JE, Howell A, Knauf M, Ooi P, Smith RP, Weise P, Wetherell M, et al. 2004. Vaccine potential of the Neisseria meningitidis 2086 lipoprotein. Infect Immun [Internet]. [cited 2017 Jan 19]; 72:2088100. Available from: http://www.ncbi.nlm.nih.gov/pubmed/15039331

Foltyn Zadura A, Zipfel PF, Bokarewa MI, Sturfelt G, Jönsen A, Nilsson SC, Hillarp A, Saxne T, Trouw LA, Blom AM. 2012. Factor H autoantibodies and deletion of Complement Factor H-Related protein-1 in rheumatic diseases in comparison to atypical hemolytic uremic syndrome. Arthritis Res Ther [Internet]. [cited 2016 Oct 30]; 14:R185. Available from: http://www.ncbi.nlm.nih.gov/pubmed/22894814

Frasch CE, Borrow R, Donnelly J. 2009. Bactericidal antibody is the immunologic surrogate of protection against meningococcal disease. Vaccine [Internet]. [cited 2015 Sep 6]; 27 Suppl 2:B112-6. Available from: http://www.ncbi.nlm.nih.gov/pubmed/19464093

Frosi G, Biolchi A, Sapio M Lo, Rigat F, Gilchrist S, Lucidarme J, Findlow J, Borrow R, Pizza M, Giuliani MM, Medini D. 2013. Bactericidal antibody against a representative epidemiological meningococcal serogroup B panel confirms that MATS underestimates 4CMenB vaccine strain coverage. Vaccine [Internet]. [cited 2016 Aug 31]; 31:4968-4974. Available from:

https://www.ncbi.nlm.nih.gov/pubmed/23954380

Gasparini R, Landa P, Amicizia D, Icardi G, Ricciardi W, de Waure C, Tanfani E, 
Bonanni P, Lucioni C, Testi A, Panatto D. 2016. Vaccinating Italian infants with a new multicomponent vaccine (Bexsero ${ }^{\circledR}$ ) against meningococcal $B$ disease: A costeffectiveness analysis. Hum Vaccin Immunother [Internet]. [cited 2016 Oct 31]; 12:2148-2161. Available from: http://www.ncbi.nlm.nih.gov/pubmed/27163398

Giuliani MM, Adu-Bobie J, Comanducci M, Aricò B, Savino S, Santini L, Brunelli B, Bambini S, Biolchi A, Capecchi B, et al. 2006. A universal vaccine for serogroup B meningococcus. Proc Natl Acad Sci U S A [Internet]. [cited 2015 Apr 14]; 103:10834-9. Available from: http://www.ncbi.nlm.nih.gov/pubmed/16825336

Gossger N, Snape MD, Yu L-M, Finn A, Bona G, Esposito S, Principi N, DiezDomingo J, Sokal E, Becker B, et al. 2012. Immunogenicity and tolerability of recombinant serogroup B meningococcal vaccine administered with or without routine infant vaccinations according to different immunization schedules: a randomized controlled trial. JAMA [Internet]. [cited 2016 Oct 10]; 307:573-82. Available from: http://www.ncbi.nlm.nih.gov/pubmed/22318278

Granoff DM. 2010. Review of meningococcal group B vaccines. Clin Infect Dis [Internet]. [cited 2015 Feb 27]; 50 Suppl 2:S54-65. Available from: http://cid.oxfordjournals.org/content/50/Supplement_2/S54.full

Griffiss JM, Brandt BL, Altieri PL, Pier GB, Berman SL. 1981. Safety and immunogenicity of group Y and group W135 meningococcal capsular polysaccharide vaccines in adults. Infect Immun [Internet]. [cited 2016 Aug 26]; 34:725-32. Available from: http://www.ncbi.nlm.nih.gov/pubmed/6800954

Gruber MF. 2015. Bexsero - Summary Basis for Regulatory Action. [place unknown]; [cited 2017 Mar 15]. Available from: https://www.fda.gov/downloads/BiologicsBloodVaccines/Vaccines/ApprovedProduct s/UCM434748.pdf

Harris SL, Zhu D, Murphy E, McNeil LK, Wang X, Mayer LW, Harrison LH, Jansen KU, Anderson AS. 2011. Preclinical evidence for the potential of a bivalent fHBP vaccine to prevent Neisseria meningitidis Serogroup C Disease. Hum Vaccin [Internet]. [cited 2016 Oct 31]; 7 Suppl:68-74. Available from: http://www.ncbi.nlm.nih.gov/pubmed/21245657

Harrison LH, Trotter CL, Ramsay ME. 2009. Global epidemiology of meningococcal disease. Vaccine [Internet]. [cited 2015 Sep 11]; 27 Suppl 2:B51-63. Available from: http://www.ncbi.nlm.nih.gov/pubmed/19477562

Holst J, Feiring B, Fuglesang JE, Høiby EA, Nøkleby H, Aaberge IS, Rosenqvist E. 2003. Serum bactericidal activity correlates with the vaccine efficacy of outer membrane vesicle vaccines against Neisseria meningitidis serogroup B disease. Vaccine [Internet]. [cited 2016 Aug 26]; 21:734-7. Available from: http://www.ncbi.nlm.nih.gov/pubmed/12531351

Holst J, Martin D, Arnold R, Huergo CC, Oster P, O’Hallahan J, Rosenqvist E. 2009. Properties and clinical performance of vaccines containing outer membrane vesicles from Neisseria meningitidis. Vaccine [Internet]. [cited 2016 Oct 19]; 27:B3B12. Available from: https://www.ncbi.nlm.nih.gov/pubmed/19481313 
Jafri RZ, Ali A, Messonnier NE, Tevi-Benissan C, Durrheim D, Eskola J, Fermon F, Klugman KP, Ramsay M, Sow S, et al. 2013. Global epidemiology of invasive meningococcal disease. Popul Health Metr [Internet]. [cited 2016 Sep 2]; 11:17. Available from: http://pophealthmetrics.biomedcentral.com/articles/10.1186/14787954-11-17

JCVI. 2014. JCVI position statement on use of Bexsero® meningococcal B vaccine in the UK [Internet]. [cited 2016 Nov 15]. Available from: https://www.gov.uk/government/publications/meningococcal-b-vaccine-jcvi-positionstatement

Jeppesen CA, Snape MD, Robinson H, Gossger N, John TM, Voysey M, Ladhani S, Okike IO, Oeser C, Kent A, et al. 2015. Meningococcal carriage in adolescents in the United Kingdom to inform timing of an adolescent vaccination strategy. J Infect [Internet]. [cited 2016 Nov 9]; 71:43-52. Available from: http://linkinghub.elsevier.com/retrieve/pii/S0163445315000651

Jiang H-Q, Hoiseth SK, Harris SL, McNeil LK, Zhu D, Tan C, Scott AA, Alexander K, Mason K, Miller L, et al. 2010. Broad vaccine coverage predicted for a bivalent recombinant factor $\mathrm{H}$ binding protein based vaccine to prevent serogroup $\mathrm{B}$ meningococcal disease. Vaccine [Internet]. [cited 2015 Sep 1]; 28:6086-93. Available from: http://www.ncbi.nlm.nih.gov/pubmed/20619376

Jones R. 2011. Costs of paediatric assessment. Br J Healthc Manag [Internet]. [cited 2016 Oct 30]; 17:57-63. Available from: http://www.magonlinelibrary.com/doi/abs/10.12968/bjhc.2011.17.2.57

Jongerius I, Lavender H, Tan L, Ruivo N, Exley RM, Caesar JJE, Lea SM, Johnson S, Tang CM, Van D, et al. 2013. Distinct Binding and Immunogenic Properties of the Gonococcal Homologue of Meningococcal Factor H Binding Protein.Nassif X, editor. PLoS Pathog [Internet]. [cited 2016 Oct 27]; 9:e1003528. Available from: http://dx.plos.org/10.1371/journal.ppat.1003528

Keiser PB, Biggs-Cicatelli S, Moran EE, Schmiel DH, Pinto VB, Burden RE, Miller LB, Moon JE, Bowden RA, Cummings JF, Zollinger WD. 2011. A phase 1 study of a meningococcal native outer membrane vesicle vaccine made from a group B strain with deleted lpxL1 and syn X, over-expressed factor $\mathrm{H}$ binding protein, two PorAs and stabilized OpcA expression. Vaccine [Internet]. [cited 2016 Sep 2]; 29:1413-20. Available from: http://www.ncbi.nlm.nih.gov/pubmed/21199704

Kimura A, Toneatto D, Kleinschmidt A, Wang H, Dull P. 2011. Immunogenicity and safety of a multicomponent meningococcal serogroup $B$ vaccine and a quadrivalent meningococcal CRM197 conjugate vaccine against serogroups A, C, W135, and $Y$ in adults who are at increased risk for occupational exposure to meningococcal . Clin Vaccine Immunol [Internet]. 18:483-6. Available from: http://www.ncbi.nlm.nih.gov/pubmed/21177912

Konar M, Granoff DM, Beernink PT. 2013. Importance of inhibition of binding of complement factor $\mathrm{H}$ for serum bactericidal antibody responses to meningococcal factor H-binding protein vaccines. J Infect Dis [Internet]. [cited 2015 Sep 1]; 208:627-36. Available from: http://jid.oxfordjournals.org/content/208/4/627.full 
Konar M, Pajon R, Beernink PT. 2015. A meningococcal vaccine antigen engineered to increase thermal stability and stabilize protective epitopes. Proc Natl Acad Sci [Internet]. [cited 2016 Nov 15]; 112:14823-14828. Available from: http://www.pnas.org/lookup/doi/10.1073/pnas.1507829112

Ladhani SN, Ramsay M, Borrow R, Riordan A, Watson JM, Pollard AJ. 2016. Enter B and W: two new meningococcal vaccine programmes launched. Arch Dis Child [Internet]. [cited 2016 Sep 5]; 101:91-5. Available from: http://www.ncbi.nlm.nih.gov/pubmed/26672098

van der Ley P, Biezen J van der, Poolman JT. 1995. Construction of Neisseria meningitidis strains carrying multiple chromosomal copies of the porA gene for use in the production of a multivalent outer membrane vesicle vaccine. Vaccine [Internet]. [cited 2016 Aug 26]; 13:401-407. Available from: http://linkinghub.elsevier.com/retrieve/pii/0264410X9598264B

van der Ley P, van den Dobbelsteen G. 2011. Next-generation outer membrane vesicle vaccines against Neisseria meningitidis based on nontoxic LPS mutants. Hum Vaccin [Internet]. [cited 2016 Oct 31]; 7:886-90. Available from: http://www.ncbi.nlm.nih.gov/pubmed/21785281

van der Ley P, Heckels JE, Virji M, Hoogerhout P, Poolman JT. 1991. Topology of outer membrane porins in pathogenic Neisseria spp. Infect Immun [Internet]. [cited 2017 Jan 23]; 59:2963-71. Available from:

http://www.ncbi.nlm.nih.gov/pubmed/1652557

Lucidarme J, Comanducci M, Findlow J, Gray SJ, Kaczmarski EB, Guiver M, Kugelberg E, Vallely PJ, Oster P, Pizza M, et al. 2009. Characterization of fHbp, nhba (gna2132), nadA, porA, sequence type (ST), and genomic presence of IS1301 in group B meningococcal ST269 clonal complex isolates from England and Wales. J Clin Microbiol [Internet]. [cited 2016 Oct 11]; 47:3577-85. Available from: http://www.ncbi.nlm.nih.gov/pubmed/19759227

Lucidarme J, Comanducci M, Findlow J, Gray SJ, Kaczmarski EB, Guiver M, Vallely PJ, Oster P, Pizza M, Bambini S, et al. 2010. Characterization of fHbp, nhba (gna2132), nadA, porA, and sequence type in group B meningococcal case isolates collected in England and Wales during January 2008 and potential coverage of an investigational group B meningococcal vaccine. Clin Vaccine Immunol [Internet]. [cited 2017 Jan 10]; 17:919-29. Available from: http://www.ncbi.nlm.nih.gov/pubmed/20375242

Lucidarme J, Tan L, Exley RM, Findlow J, Borrow R, Tang CM. 2011. Characterization of Neisseria meningitidis isolates that do not express the virulence factor and vaccine antigen factor $\mathrm{H}$ binding protein. Clin Vaccine Immunol [Internet]. [cited 2017 Jan 10]; 18:1002-14. Available from: http://www.ncbi.nlm.nih.gov/pubmed/21508163

Luo Y, Friese O V., Runnels HA, Khandke L, Zlotnick G, Aulabaugh A, Gore T, Vidunas E, Raso SW, Novikova E, et al. 2016. The Dual Role of Lipids of the Lipoproteins in Trumenba, a Self-Adjuvanting Vaccine Against Meningococcal Meningitis B Disease. AAPS J [Internet]. [cited 2017 Jan 10]; 18:1562-1575. 
Available from: http://link.springer.com/10.1208/s12248-016-9979-x

MacLennan J, Kafatos G, Neal K, Andrews N, Cameron JC, Roberts R, Evans MR, Cann K, Baxter DN, Maiden MCJ, et al. 2006. Social behavior and meningococcal carriage in British teenagers. Emerg Infect Dis [Internet]. [cited 2017 Jan 12]; 12:950-7. Available from: http://www.ncbi.nlm.nih.gov/pubmed/16707051

Maharjan S, Saleem M, Feavers I, Wheeler J, Care R, Derrick J. 2016. Dissecting the function of the reduction modifiable protein, RmpM, from Neisseria meningitidis. In: 20th Int Pathog Neisseria Conf [Internet]. Manchester, United Kingdom. Available from: http://www.ipnc2016.org/IPNC2016AbstractBook.pdf

Marsay L, Dold C, Green CA, Rollier CS, Norheim G, Sadarangani M, Shanyinde M, Brehony C, Thompson AJ, Sanders H, et al. 2015. A novel meningococcal outer membrane vesicle vaccine with constitutive expression of FetA: A phase I clinical trial. J Infect [Internet]. [cited 2016 Nov 8]; 71:326-37. Available from: http://www.ncbi.nlm.nih.gov/pubmed/25982025

Marshall HS. 2016. B Part of It [Internet]. [cited 2017 Jan 29]. Available from: http://www.bpartofit.com.au/

Marshall HS, Chen G, Clarke M, Ratcliffe J. 2016. Adolescent, parent and societal preferences and willingness to pay for meningococcal B vaccine: A Discrete Choice Experiment. Vaccine [Internet]. [cited 2016 Nov 9]; 34:671-677. Available from: http://linkinghub.elsevier.com/retrieve/pii/S0264410X15017697

Marshall HS, Richmond PC, Beeslaar J, Jiang Q, Jansen KU, Garcés-Sánchez M, Martinón-Torres F, Szenborn L, Wysocki J, Eiden J, et al. 2016. Meningococcal serogroup B-specific responses after vaccination with bivalent rLP2086: 4 year follow-up of a randomised, single-blind, placebo-controlled, phase 2 trial. Lancet Infect Dis [Internet]. [cited 2016 Nov 9]. Available from:

http://linkinghub.elsevier.com/retrieve/pii/S1473309916303140

Marshall HS, Richmond PC, Nissen MD, Jiang Q, Anderson AS, Jansen KU, Reynolds G, Ziegler JB, Harris SL, Jones TR, Perez JL. 2012. Safety and Immunogenicity of a Meningococcal B Bivalent rLP2086 Vaccine in Healthy Toddlers Aged 18 to 36 Months. Pediatr Infect Dis J [Internet]. [cited 2017 Jan 19]:1. Available from:

http://content.wkhealth.com/linkback/openurl?sid=WKPTLP:landingpage\&an=00006 454-900000000-98647

Marshall HS, Richmond PC, Nissen MD, Wouters A, Baber J, Jiang Q, Anderson AS, Jones TR, Harris SL, Jansen KU, Perez JL. 2013. A phase 2 open-label safety and immunogenicity study of a meningococcal B bivalent rLP2086 vaccine in healthy adults. Vaccine [Internet]. [cited 2016 Aug 29]; 31:1569-75. Available from: http://www.ncbi.nlm.nih.gov/pubmed/23352429

Martin DR, Ruijne N, McCallum L, O’Hallahan J, Oster P. 2006. The VR2 epitope on the PorA P1.7-2,4 protein is the major target for the immune response elicited by the strain-specific group B meningococcal vaccine MeNZB. Clin Vaccine Immunol [Internet]. [cited 2016 Aug 26]; 13:486-91. Available from: 
http://www.ncbi.nlm.nih.gov/pubmed/16603616

Martin SL, Borrow R, van der Ley P, Dawson M, Fox AJ, Cartwright KA. 2000. Effect of sequence variation in meningococcal PorA outer membrane protein on the effectiveness of a hexavalent PorA outer membrane vesicle vaccine. Vaccine [Internet]. [cited 2016 Aug 26]; 18:2476-81. Available from: http://www.ncbi.nlm.nih.gov/pubmed/10775781

Mascioni A, Moy FJ, McNeil LK, Murphy E, Bentley BE, Camarda R, Dilts DA, Fink PS, Gusarova V, Hoiseth SK, et al. 2010. NMR dynamics and antibody recognition of the meningococcal lipidated outer membrane protein LP2086 in micellar solution. Biochim Biophys Acta - Biomembr [Internet]. [cited 2017 Jan 10]; 1798:87-93. Available from: http://www.ncbi.nlm.nih.gov/pubmed/19835839

Masignani V, Comanducci M, Giuliani MM, Bambini S, Adu-Bobie J, Arico B, Brunelli B, Pieri A, Santini L, Savino S, et al. 2003. Vaccination against Neisseria meningitidis using three variants of the lipoprotein GNA1870. J Exp Med [Internet]. [cited 2016 Aug 29]; 197:789-99. Available from:

http://www.ncbi.nlm.nih.gov/pubmed/12642606

McNeil LK, Zagursky RJ, Lin SL, Murphy E, Zlotnick GW, Hoiseth SK, Jansen KU, Anderson AS. 2013. Role of factor H binding protein in Neisseria meningitidis virulence and its potential as a vaccine candidate to broadly protect against meningococcal disease. Microbiol Mol Biol Rev [Internet]. [cited 2015 Jan 29]; 77:234-52. Available from:

http://www.pubmedcentral.nih.gov/articlerender.fcgi?artid=3668674\&tool=pmcentrez \&rendertype $=$ abstract

Medini D, Stella M, Wassil J. 2015. MATS: Global coverage estimates for 4CMenB, a novel multicomponent meningococcal B vaccine. Vaccine [Internet]. [cited 2016 Aug 31]; 33:2629-2636. Available from:

https://www.ncbi.nlm.nih.gov/pubmed/25882169

de Moraes JC, Perkins BA, Camargo MC, Hidalgo NT, Barbosa HA, Sacchi CT, Landgraf IM, Gattas VL, Vasconcelos H de G, Gral IM. 1992. Protective efficacy of a serogroup B meningococcal vaccine in Sao Paulo, Brazil. Lancet [Internet]. [cited 2016 Aug 26]; 340:1074-8. Available from:

http://www.ncbi.nlm.nih.gov/pubmed/1357461

Mulhall RM, Brehony C, O’Connor L, Meyler K, Jolley KA, Bray J, Bennett D, Maiden MCJ, Cunney R. 2016. Resolution of a Protracted Serogroup B

Meningococcal Outbreak with Whole-Genome Sequencing Shows Interspecies Genetic Transfer. J Clin Microbiol [Internet]. [cited 2017 Jan 10]; 54:2891-2899. Available from: http://www.ncbi.nlm.nih.gov/pubmed/27629899

Murphy E, Andrew L, Lee K-L, Dilts DA, Nunez L, Fink PS, Ambrose K, Borrow $\mathrm{R}$, Findlow J, Taha M-K, et al. 2009. Sequence diversity of the factor $\mathrm{H}$ binding protein vaccine candidate in epidemiologically relevant strains of serogroup B Neisseria meningitidis. J Infect Dis [Internet]. [cited 2016 Aug 29]; 200:379-89. Available from: http://www.ncbi.nlm.nih.gov/pubmed/19534597 
Nainani V, Buttery J, Snape M. 2016. Presentation to Accident and Emergency following immunization with capsular group B meningococcal vaccine. In: 20th Int Pathog Neisseria Conf [Internet]. Manchester, United Kingdom. Available from: http://www.ipnc2016.org/IPNC2016AbstractBook.pdf

Nissen MD, Marshall HS, Richmond PC, Jiang Q, Harris SL, Jones TR, Jansen KU, Perez JL. 2013. A Randomized, Controlled, Phase 1/2 Trial of a Neisseria meningitidis Serogroup B Bivalent rLP2086 Vaccine in Healthy Children and Adolescents. Pediatr Infect Dis J [Internet]. [cited 2016 Sep 4]; 32:364-371. Available from:

http://content.wkhealth.com/linkback/openurl?sid=WKPTLP:landingpage\&an=00006 454-201304000-00022

Nolan T, O’Ryan M, Wassil J, Abitbol V, Dull P. 2015. Vaccination with a multicomponent meningococcal $\mathrm{B}$ vaccine in prevention of disease in adolescents and young adults. Vaccine [Internet]. [cited 2016 Aug 30]; 33:4437-4445. Available from: https://www.ncbi.nlm.nih.gov/pubmed/26187261

Oster P, Lennon D, O’Hallahan J, Mulholland K, Reid S, Martin D. 2005. MeNZB $^{\mathrm{TM}}$ : a safe and highly immunogenic tailor-made vaccine against the New Zealand Neisseria meningitidis serogroup B disease epidemic strain. Vaccine [Internet]. [cited 2016 Aug 26]; 23:2191-2196. Available from: https://www.ncbi.nlm.nih.gov/pubmed/15755593

Ostergaard L, Lucksinger GH, Absalon J, Beeslaar J, Eiden J, Jansen KU, York LJ, Quinn A, Graversen ME, Perez JL. 2016. A phase 3, randomized, activecontrolled study to assess the safety and tolerability of meningococcal serogroup B vaccine bivalent rLP2086 in healthy adolescents and young adults. Vaccine. 34:14651471.

Pajon R, Lujan E, Granoff DM. 2016. A meningococcal NOMV-FHbp vaccine for Africa elicits broader serum bactericidal antibody responses against serogroup $\mathrm{B}$ and non-B strains than a licensed serogroup B vaccine. Vaccine [Internet]. [cited 2016 Nov 9]; 34:643-649. Available from: www.ncbi.nlm.nih.gov/pubmed/26709637

Parikh SR, Andrews NJ, Beebeejaun K, Campbell H, Ribeiro S, Ward C, White JM, Borrow R, Ramsay ME, Ladhani SN, et al. 2016. Effectiveness and impact of a reduced infant schedule of $4 \mathrm{CMenB}$ vaccine against group $\mathrm{B}$ meningococcal disease in England: a national observational cohort study. Lancet [Internet]. [cited 2016 Oct 30]; 0:91-95. Available from: http://linkinghub.elsevier.com/retrieve/pii/S0140673616319213

Partridge E, Giuntini S, Lujan E, Granoff DM. 2016. The Role of Antibodies to Neisserial Heparin Binding Antigen (NHba) in Protection Elicited by the GSK Serogroup B Meningococcal Vaccine (MenB-4C) Vaccine. Open Forum Infect Dis [Internet]. [cited 2017 Mar 14]; 3. Available from: https://academic.oup.com/ofid/article/2637161/The

Petousis-Harris H, Paynter J, Morgan J, Saxton P, Sherwood J, McArdle B, Goodyear-Smith F. 2016. Effectiveness of a group B OMV meningococcal vaccine on gonorrhoea in New Zealand - a case control study. In: 20th Int Pathog Neisseria Conf 
[Internet]. Manchester, United Kingdom. Available from:

http://www.ipnc2016.org/IPNC2016AbstractBook.pdf

Pizza M, Scarlato V, Masignani V, Giuliani MM, Aricò B, Comanducci M, Jennings GT, Baldi L, Bartolini E, Capecchi B, et al. 2000. Identification of vaccine candidates against serogroup $B$ meningococcus by whole-genome sequencing. Science [Internet]. [cited 2016 Aug 26]; 287:1816-20. Available from: http://www.ncbi.nlm.nih.gov/pubmed/10710308

Pouwels KB, Hak E, van der Ende A, Christensen H, van den Dobbelsteen GPJM, Postma MJ. 2013. Cost-effectiveness of vaccination against meningococcal B among Dutch infants. Hum Vaccin Immunother [Internet]. [cited 2016 Oct 31]; 9:1129-1138. Available from: http://www.tandfonline.com/doi/abs/10.4161/hv.23888

Prymula R, Esposito S, Zuccotti GV, Xie F, Toneatto D, Kohl I, Dull PM. 2014. A phase 2 randomized controlled trial of a multicomponent meningococcal serogroup B vaccine (I). Hum Vaccin Immunother [Internet]. [cited 2015 Sep 29]; 10:19932004. Available from: http://www.ncbi.nlm.nih.gov/pubmed/25424809

Public Health England. 2015. Introduction of MenB immunisation for infants [Internet]. London, United Kingdom; [cited 2016 Nov 21]. Available from: https://www.gov.uk/government/uploads/system/uploads/attachment_data/file/437906 /150622_MenB_bipartite_letter.pdf

Rappuoli R, Covacci A. 2003. Reverse vaccinology and genomics. Science [Internet]. [cited 2016 Aug 26]; 302:602. Available from: http://www.ncbi.nlm.nih.gov/pubmed/14576423

Read RC, Baxter D, Chadwick DR, Faust SN, Finn A, Gordon SB, Heath PT, Lewis DJM, Pollard AJ, Turner DPJ, et al. 2014. Effect of a quadrivalent meningococcal ACWY glycoconjugate or a serogroup B meningococcal vaccine on meningococcal carriage: an observer-blind, phase 3 randomised clinical trial. Lancet [Internet]. [cited 2016 Aug 31]; 384:2123-2131. Available from: http://linkinghub.elsevier.com/retrieve/pii/S0140673614608424

Richmond PC, Marshall HS, Nissen MD, Jiang Q, Jansen KU, Garcés-Sánchez M, Martinón-Torres F, Beeslaar J, Szenborn L, Wysocki J, et al. 2012. Safety, immunogenicity, and tolerability of meningococcal serogroup B bivalent recombinant lipoprotein 2086 vaccine in healthy adolescents: a randomised, single-blind, placebocontrolled, phase 2 trial. Lancet Infect Dis [Internet]. [cited 2016 Aug 29]; 12:597607. Available from: http://www.ncbi.nlm.nih.gov/pubmed/22569484

Rietschel ET, Brade L, Schade U, Seydel U, Zähringer U, Brandenburg K, Helander I, Holst O, Kondo S, Kuhn HM. 1990. Bacterial lipopolysaccharides: relationship of structure and conformation to endotoxic activity, serological specificity and biological function. Adv Exp Med Biol [Internet]. [cited 2016 Oct 6]; 256:81-99. Available from: http://www.ncbi.nlm.nih.gov/pubmed/2183574

Rossi R, Konar M, Beernink PT. 2016. Meningococcal Factor H Binding Protein Vaccine Antigens with Increased Thermal Stability and Decreased Binding of Human Factor H.Pirofski L, editor. Infect Immun [Internet]. [cited 2016 Nov 9]; 84:1735- 
1742. Available from: http://iai.asm.org/lookup/doi/10.1128/IAI.01491-15

Russell JE, Jolley KA, Feavers IM, Maiden MCJ, Suker J. 2004. PorA variable regions of Neisseria meningitidis. Emerg Infect Dis [Internet]. [cited 2017 Jan 23]; 10:674-8. Available from: http://www.ncbi.nlm.nih.gov/pubmed/15200858

Sacchi CT, Lemos APS, Popovic T, Cassio de Morais J, Whitney AM, Melles CEA, Brondi LMG, Monteiro LMC, Paiva M V., Solari CA, Mayer LW. 2001. Serosubtypes and PorA Types of Neisseria meningitidis Serogroup B Isolated in Brazil during 1997-1998: Overview and Implications for Vaccine Development. J Clin Microbiol [Internet]. [cited 2016 Aug 26]; 39:2897-2903. Available from: http://jcm.asm.org/cgi/doi/10.1128/JCM.39.8.2897-2903.2001

Sanders H, Norheim G, Chan H, Dold C, Vipond C, Derrick JP, Pollard AJ, Maiden MCJ, Feavers IM. 2015. FetA Antibodies Induced by an Outer Membrane Vesicle Vaccine Derived from a Serogroup B Meningococcal Isolate with Constitutive FetA Expression. PLoS One [Internet]. [cited 2016 Nov 8]; 10:e0140345. Available from: http://www.ncbi.nlm.nih.gov/pubmed/26466091

Santolaya ME, O’Ryan ML, Valenzuela MT, Prado V, Vergara R, Muñoz A, Toneatto D, Graña G, Wang H, Clemens R, et al. 2012. Immunogenicity and tolerability of a multicomponent meningococcal serogroup $\mathrm{B}$ (4CMenB) vaccine in healthy adolescents in Chile: a phase 2b/3 randomised, observer-blind, placebocontrolled study. Lancet (London, England) [Internet]. [cited 2016 Aug 31]; 379:61724. Available from: http://www.ncbi.nlm.nih.gov/pubmed/22260988

Saukkonen K, Leinonen M, Abdillahi H, Poolman JT. 1989. Comparative evaluation of potential components for group B meningococcal vaccine by passive protection in the infant rat and in vitro bactericidal assay. Vaccine [Internet]. [cited 2016 Aug 26]; 7:325-328. Available from:

http://linkinghub.elsevier.com/retrieve/pii/0264410X89901941

Serruto D, Bottomley MJ, Ram S, Giuliani MM, Rappuoli R. 2012. The new multicomponent vaccine against meningococcal serogroup B, 4CMenB:

immunological, functional and structural characterization of the antigens. Vaccine [Internet]. [cited 2015 Sep 5]; 30 Suppl 2:B87-97. Available from:

http://www.pubmedcentral.nih.gov/articlerender.fcgi?artid=3360877\&tool=pmcentrez \&rendertype $=$ abstract

Serruto D, Spadafina T, Ciucchi L, Lewis LA, Ram S, Tontini M, Santini L, Biolchi A, Seib KL, Giuliani MM, et al. 2010. Neisseria meningitidis GNA2132, a heparin-binding protein that induces protective immunity in humans. Proc Natl Acad Sci [Internet]. [cited 2017 Jan 19]; 107:3770-3775. Available from: http://www.ncbi.nlm.nih.gov/pubmed/20133713

Sexton K, Lennon D, Oster P, Aaberge I, Martin D, Reid S, Wong S, O’Hallahan J. 2004. Proceedings of the Meningococcal Vaccine Strategy World Health Organization satellite meeting, 10 March 2004, Auckland, New Zealand. N Z Med J [Internet]. [cited 2016 Oct 21]; 117:1 p preceding U1027. Available from: http://www.ncbi.nlm.nih.gov/pubmed/15481128 
Shea MW. 2013. The Long Road to an Effective Vaccine for Meningococcus Group B (MenB). Ann Med Surg [Internet]. [cited 2015 Oct 2]; 2:53-6. Available from: http://www.sciencedirect.com/science/article/pii/S2049080113700372

Sierra G V, Campa HC, Varcacel NM, Garcia IL, Izquierdo PL, Sotolongo PF, Casanueva G V, Rico CO, Rodriguez CR, Terry MH. 1991. Vaccine against group B Neisseria meningitidis: protection trial and mass vaccination results in Cuba. NIPH Ann [Internet]. [cited 2016 Aug 26]; 14:195-207-10. Available from: http://www.ncbi.nlm.nih.gov/pubmed/1812432

Smith M. 2016. Trumenba - Summary Basis for Regulatory Action. [place unknown]; [cited 2017 Mar 15]. Available from:

https://www.fda.gov/downloads/BiologicsBloodVaccines/Vaccines/ApprovedProduct s/UCM496484.pdf

Snape MD, Dawson T, Oster P, Evans A, John TM, Ohene-Kena B, Findlow J, Yu L-M, Borrow R, Ypma E, et al. 2010. Immunogenicity of two investigational serogroup $\mathrm{B}$ meningococcal vaccines in the first year of life: a randomized comparative trial. Pediatr Infect Dis J [Internet]. [cited 2016 Aug 31]; 29:e71-9. Available from: http://www.ncbi.nlm.nih.gov/pubmed/20844462

Snape MD, Saroey P, John TM, Robinson H, Kelly S, Gossger N, Yu L-M, Wang H, Toneatto D, Dull PM, Pollard AJ. 2013. Persistence of bactericidal antibodies following early infant vaccination with a serogroup B meningococcal vaccine and immunogenicity of a preschool booster dose. CMAJ [Internet]. [cited 2016 Aug 31]; 185:E715-24. Available from: http://www.ncbi.nlm.nih.gov/pubmed/24062178

Snape MD, Voysey M, Finn A, Bona G, Esposito S, Principi N, Diez-Domingo J, Sokal E, Kieninger D, Prymula R, et al. 2016. Persistence of Bactericidal Antibodies After Infant Serogroup B Meningococcal Immunization and Booster Dose Response at 12, 18 or 24 Months of Age. Pediatr Infect Dis J [Internet]. [cited 2016 Sep 2]; 35:e113-23. Available from: http://www.ncbi.nlm.nih.gov/pubmed/26756390

Soeter H, Mcnamara L, Whaley M, Wang X, Alexander-Scott N, Goodwin K, Kanadanian K, Kelleher C, Macneil J, Martin S, et al. 2015. Meningococcal Carriage Evaluation in Response to a Serogroup B Meningococcal Disease Outbreak and Mass Vaccination Campaign at a College in Rhode Island, 2015. In: IDWeek 2015 [Internet]. San Diego, CA. Available from:

https://idsa.confex.com/idsa/2015/webprogram/Paper50595.html

Sun W. 2017. Trumenba - FDA Supplement Approval [Internet]. [cited 2017 Apr 3]. Available from:

https://www.fda.gov/downloads/BiologicsBloodVaccines/Vaccines/ApprovedProduct s/UCM547476.pdf

Tappero JW, Lagos R, Maldonado Ballesteros A, Plikaytis B, Williams D, Dykes J, Gheesling LL, Carlone GM, Høiby EA, Holst J, et al. 1999. Immunogenicity of 2 Serogroup B Outer-Membrane Protein Meningococcal Vaccines. JAMA [Internet]. [cited 2016 Aug 26]; 281:497-500. Available from: http://jama.jamanetwork.com/article.aspx?doi=10.1001/jama.281.16.1520 
Tauseef I, Ali YM, Bayliss CD. 2013. Phase variation of PorA, a major outer membrane protein, mediates escape of bactericidal antibodies by Neisseria meningitidis. Infect Immun [Internet]. [cited 2016 Oct 14]; 81:1374-80. Available from: http://www.ncbi.nlm.nih.gov/pubmed/23403557

Tettelin H, Saunders NJ, Heidelberg J, Jeffries AC, Nelson KE, Eisen JA, Ketchum KA, Hood DW, Peden JF, Dodson RJ, et al. 2000. Complete genome sequence of Neisseria meningitidis serogroup B strain MC58. Science [Internet]. [cited 2016 Oct 14]; 287:1809-15. Available from: http://www.ncbi.nlm.nih.gov/pubmed/10710307

Tirani M, Meregaglia M, Melegaro A. 2015. Health and economic outcomes of introducing the new MenB vaccine (Bexsero) into the Italian routine infant immunisation programme. PLoS One [Internet]. [cited 2016 Oct 30]; 10:e0123383. Available from: http://www.ncbi.nlm.nih.gov/pubmed/25874805

Tondella ML, Popovic T, Rosenstein NE, Lake DB, Carlone GM, Mayer LW, Perkins BA. 2000. Distribution of Neisseria meningitidis serogroup B serosubtypes and serotypes circulating in the United States. The Active Bacterial Core Surveillance Team. J Clin Microbiol [Internet]. [cited 2015 Apr 13]; 38:3323-8. Available from: http://www.pubmedcentral.nih.gov/articlerender.fcgi?artid=87381\&tool=pmcentrez\& rendertype $=$ abstract

Toneatto D, Ismaili S, Ypma E, Vienken K, Oster P, Dull P. 2011. The first use of an investigational multicomponent meningococcal serogroup $\mathrm{B}$ vaccine (4CMenB) in humans. Hum Vaccin [Internet]. [cited 2016 Oct 10]; 7:646-53. Available from: http://www.ncbi.nlm.nih.gov/pubmed/21904120

Trotter CL, Gay NJ, Edmunds WJ. 2005. Dynamic Models of Meningococcal Carriage, Disease, and the Impact of Serogroup C Conjugate Vaccination. Am J Epidemiol [Internet]. [cited 2016 Oct 19]; 162:89-100. Available from: http://www.ncbi.nlm.nih.gov/pubmed/15961591

Trotter CL, Maiden MC. 2009. Meningococcal vaccines and herd immunity: lessons learned from serogroup $C$ conjugate vaccination programs. Expert Rev Vaccines [Internet]. [cited 2016 Sep 6]; 8:851-861. Available from: http://www.tandfonline.com/doi/full/10.1586/erv.09.48

Urwin R, Russell JE, Thompson EAL, Holmes EC, Feavers IM, Maiden MCJ. 2004. Distribution of surface protein variants among hyperinvasive meningococci: implications for vaccine design. Infect Immun [Internet]. [cited 2015 Sep 1]; 72:5955-62. Available from:

http://www.pubmedcentral.nih.gov/articlerender.fcgi?artid=517544\&tool=pmcentrez \&rendertype $=$ abstract

Vacca I, Del Tordello E, Gasperini G, Pezzicoli A, Di Fede M, Rossi Paccani S, Marchi S, Mubaiwa TD, Hartley-Tassell LE, Jennings MP, et al. 2016. Neisserial Heparin Binding Antigen (NHBA) Contributes to the Adhesion of Neisseria meningitidis to Human Epithelial Cells.Stevenson B, editor. PLoS One [Internet]. [cited 2017 Mar 14]; 11:e0162878. Available from: http://dx.plos.org/10.1371/journal.pone.0162878 
Vesikari T, Esposito S, Prymula R, Ypma E, Kohl I, Toneatto D, Dull P, Kimura A. 2013. Immunogenicity and safety of an investigational multicomponent, recombinant, meningococcal serogroup B vaccine (4CMenB) administered concomitantly with routine infant and child vaccinations: results of two randomised trials. Lancet [Internet]. [cited 2016 Oct 10]; 381:825-835. Available from: http://linkinghub.elsevier.com/retrieve/pii/S0140673612619618

Vesikari T, Wysocki J, Beeslaar J, Eiden J, Jiang Q, Jansen KU, Jones TR, Harris SL, O’Neill RE, York LJ, Perez JL. 2016. Immunogenicity, Safety, and Tolerability of Bivalent rLP2086 Meningococcal Group B Vaccine Administered Concomitantly With Diphtheria, Tetanus, and Acellular Pertussis and Inactivated Poliomyelitis Vaccines to Healthy Adolescents. J Pediatric Infect Dis Soc [Internet]. [cited 2016 Aug 29]; 5:180-187. Available from: http://jpids.oxfordjournals.org/lookup/doi/10.1093/jpids/piv064

Vetter V, Baxter R, Denizer G, Sáfadi MAP, Silfverdal S-A, Vyse A, Borrow R. 2016. Routinely vaccinating adolescents against meningococcus: targeting transmission disease. Expert Rev Vaccines [Internet]. [cited 2016 Oct 19]; 15:641-58. Available from: http://www.ncbi.nlm.nih.gov/pubmed/26651380

Vogel U, Taha M-K, Vazquez JA, Findlow J, Claus H, Stefanelli P, Caugant DA, Kriz P, Abad R, Bambini S, et al. 2013. Predicted strain coverage of a meningococcal multicomponent vaccine (4CMenB) in Europe: a qualitative and quantitative assessment. Lancet Infect Dis [Internet]. [cited 2016 Sep 5]; 13:416-25. Available from: http://www.ncbi.nlm.nih.gov/pubmed/23414709

De Wals P. 2015. Results of a mass immunisation campaign with 4-components serogroup B meningococcal vaccine (4CMenB) in Quebec, Canada. In: Meningitis Septicaemia Child Adults [Internet]. London, United Kingdom. Available from: http://www.meningitis.org/conference2015

van de Waterbeemd B, Streefland M, van der Ley P, Zomer B, van Dijken H, Martens D, Wijffels R, van der Pol L. 2010. Improved OMV vaccine against Neisseria meningitidis using genetically engineered strains and a detergent-free purification process. Vaccine [Internet]. [cited 2016 Aug 26]; 28:4810-6. Available from: http://www.ncbi.nlm.nih.gov/pubmed/20483197

van de Waterbeemd B, Zomer G, Kaaijk P, Ruiterkamp N, Wijffels RH, van den Dobbelsteen GPJM, van der Pol LA. 2013. Improved production process for native outer membrane vesicle vaccine against Neisseria meningitidis. PLoS One [Internet]. [cited 2016 Sep 2]; 8:e65157. Available from:

http://www.ncbi.nlm.nih.gov/pubmed/23741478

Weynants VE, Feron CM, Goraj KK, Bos MP, Denoël PA, Verlant VG, Tommassen J, Peak IRA, Judd RC, Jennings MP, Poolman JT. 2007. Additive and synergistic bactericidal activity of antibodies directed against minor outer membrane proteins of Neisseria meningitidis. Infect Immun [Internet]. [cited 2016 Oct 19]; 75:5434-42. Available from: http://www.ncbi.nlm.nih.gov/pubmed/17664268

Williams JN, Skipp PJ, Humphries HE, Christodoulides M, O’Connor CD, Heckels JE. 2007. Proteomic analysis of outer membranes and vesicles from wild- 
type serogroup B Neisseria meningitidis and a lipopolysaccharide-deficient mutant. Infect Immun [Internet]. [cited 2016 Nov 18]; 75:1364-72. Available from:

http://www.ncbi.nlm.nih.gov/pubmed/17158897

Zlotnick GW, Jones TR, Liberator P, Hao L, Harris S, McNeil LK, Zhu D, Perez J, Eiden J, Jansen KU, Anderson AS. 2015. The Discovery and Development of a Novel Vaccine to Protect against Neisseria meningitidis Serogroup B Disease. Hum Vaccin Immunother [Internet]. [cited 2016 Aug 29]; 11:5-13. Available from: http://www.tandfonline.com/doi/abs/10.4161/hv.34293 
Table 1. A summary of key examples utilising OMV vaccines during strain-dominant epidemics (Bjune et al. 1991; Sierra et al. 1991; de Moraes et al. 1992; Tappero et al. 1999; Oster et al. 2005; Caron et al. 2011).

\begin{tabular}{|c|c|c|c|c|}
\hline $\begin{array}{l}\text { Country of } \\
\text { Epidemic }\end{array}$ & $\begin{array}{l}\text { Dominant } \\
\text { strain }\end{array}$ & $\begin{array}{l}\text { Vaccine(s) } \\
\text { (Derived from strain) }\end{array}$ & Studies & $\begin{array}{l}\text { Efficacy }{ }^{\mathbf{a}, \mathbf{b}} \\
\text { (\# of doses) }\end{array}$ \\
\hline Cuba & B:4:P1.15 & $\begin{array}{l}\text { VA-MENGOC-BC } \\
\text { (B:4:P1.15) }\end{array}$ & $\begin{array}{l}\text { Randomized } \\
\text { Controlled Trial } \\
\text { G. Sierra et al. } 1991 .\end{array}$ & $\begin{array}{l}\text { 10-14y: } 83 \% \mathrm{p}<0.002^{\mathrm{a}} \\
\text { (2 doses) }\end{array}$ \\
\hline Norway & B:15:P1.7 & $\begin{array}{l}\text { MenBvac }^{\mathrm{R}} \\
(\mathrm{B}: 15: \mathrm{P} 1.7)\end{array}$ & $\begin{array}{l}\text { Randomized } \\
\text { Controlled Trial } \\
\text { G. Bjune et al. } 1991\end{array}$ & $\begin{array}{l}\text { 14-16y: } 57 \% \mathrm{p}<0.012^{\text {a }} \\
\text { (2 doses) }\end{array}$ \\
\hline Brazil & B:15:P1.15 & $\begin{array}{l}\text { VA-MENGOC-BC } \\
\text { (B:4:P1.15) }\end{array}$ & $\begin{array}{l}\text { Case-Control Study } \\
\text { J. de Moraes et al. } \\
1992\end{array}$ & $\begin{array}{l}<\mathbf{2 4 m}:-37 \%^{a} \\
(95 \% \text { CI }-100 \%-73 \%) \\
\text { 24-47m: } 47 \%^{a} \\
(95 \% \text { CI }-72 \%-84 \%) \\
\mathbf{4 8 m - 6 y : ~} 74 \% \text { a } \\
\text { (95\% CI } 16 \%-92 \%) \\
\text { (2 doses) }\end{array}$ \\
\hline Chile & B:15:P1.3 & $\begin{array}{l}\text { VA-MENGOC-BC } \\
\text { (B:4:P1.15) } \\
\text { MenBvac }^{\mathbf{R}} \\
\text { (B:15:P1.7) }\end{array}$ & $\begin{array}{l}\text { Randomized } \\
\text { Controlled Trial } \\
\text { J. Tappero et al. } 1999 .\end{array}$ & 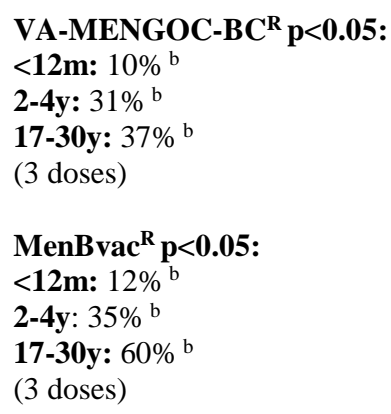 \\
\hline New Zealand & B:4:P1.7b & $\begin{array}{l}\text { MeNZBR } \\
\text { (B:4:P1.7b) }\end{array}$ & $\begin{array}{l}\text { Randomized } \\
\text { Controlled Trials. } \\
\text { P. Oster et al. } 2005 .\end{array}$ & $\begin{array}{l}\text { 6-8m: } 74 \%^{\mathrm{b}} \\
\text { (95\% CI 67\% - 80\%) } \\
\text { 16-24m: 75\% }{ }^{\mathrm{b}} \\
(95 \% \text { CI } 68 \%-80 \%) \\
\mathbf{8 - 1 2 y : ~ 7 6 \% ~}{ }^{\mathrm{b}} \\
(95 \% \text { CI } 72 \%-80 \%) \\
\text { >18y: } 96 \%^{\mathrm{b}} \\
\text { (95\% CI 79\% - 100\%) } \\
\text { (2 doses and a booster) }\end{array}$ \\
\hline France & B:14:P1.7,16 & $\begin{array}{l}\text { MenBvac }^{\mathbf{R}} \\
(\mathrm{B}: 15: \mathrm{P} 1.7)\end{array}$ & $\begin{array}{l}\text { Random sampling of } \\
\text { vaccinated } \\
\text { individuals. } \\
\text { F. Caron et al. } 2011\end{array}$ & $\begin{array}{l}\text { 1-5y: 88\% b } \\
\text { (95\% CI 86-90\%) }\end{array}$ \\
\hline
\end{tabular}

a. Efficacy measured as percentage of case reduction in vaccinees

b. Efficacy measured as percentage of vaccinees with a rise in hSBA titre of $\geq 1: 4$ 
Table 2. A summary of key developmental clinical trials for rLP2086 (Richmond et al. 2012; Marshall et al. 2013; Nissen et al. 2013; Vesikari et al. 2016).

\begin{tabular}{|c|c|c|c|}
\hline Study & Strains tested against & $\begin{array}{l}\text { Number of } \\
\text { participants } \\
\text { (Age) }\end{array}$ & $\begin{array}{l}\text { Efficacy one month after } \\
\text { three doses } \mathbf{a , b} \\
\text { (dosing schedule) }\end{array}$ \\
\hline $\begin{array}{l}\text { Phase II randomised } \\
\text { controlled trial (Australia, } \\
\text { Poland and Spain) } \\
\text { P. Richmond et al. } 2012\end{array}$ & $\begin{array}{l}\text { PMB3302 (fHbp A04) } \\
\text { PMB1745 (fHbp A05)* } \\
\text { PMB2001 (fHbp A56) } \\
\text { PMB1321 (fHbp A22) } \\
\text { PMB2707 (fHbp B44) } \\
\text { PMB2948 (fHbp B24) } \\
\text { PMB1256 (fHbp B03) } \\
\text { PMB17 (fHbp B02)* }\end{array}$ & $\begin{array}{l}536 \text { Healthy } \\
\text { adolescents } \\
(11-18 y)\end{array}$ & $\begin{array}{l}\mathbf{7 5 . 6 \%}-\mathbf{1 0 0} \% \text { across } 8 \\
\text { strains }^{\mathbf{a}} \\
(0,2 \text { and } 6 \text { months })\end{array}$ \\
\hline $\begin{array}{l}\text { Phase I/II randomised } \\
\text { controlled trial (Australia) } \\
\text { D. Nissen et al. } 2013\end{array}$ & $\begin{array}{l}\text { PMB1745 (fHbp A05)* } \\
\text { PMB17 } \quad \text { (fHbp B02)* }\end{array}$ & $\begin{array}{l}127 \text { Healthy } \\
\text { adolescents } \\
(8-14 y)\end{array}$ & $\begin{array}{l}\mathbf{6 8 . 8} \%-\mathbf{9 5 . 3} \% \text { across } 2 \\
\text { strains } \\
(0,1 \text { and } 6 \text { months })\end{array}$ \\
\hline $\begin{array}{l}\text { Phase II open-label } \\
\text { clinical trial (Australia) } \\
\text { H. Marshall et al. } 2013\end{array}$ & $\begin{array}{l}\text { PMB1745 (fHbp A05)* } \\
\text { PMB17 (fHbp B02)* } \\
\text { PMB1321 (fHbp A22) } \\
\text { PMB2707 (fHbp B44) } \\
\text { PMB2948 (fHbp B24) }\end{array}$ & $\begin{array}{l}55 \text { Healthy } \\
\text { adults } \\
(18-40 y)\end{array}$ & $\begin{array}{l}\mathbf{8 1} \%-\mathbf{9 4 \%} \text { across } 5 \text { strains }^{\mathbf{a}} \\
(0,1 \text { and } 6 \text { months })\end{array}$ \\
\hline $\begin{array}{l}\text { Randomised controlled } \\
\text { trial } \\
\text { (Finland) } \\
\text { T. Vesikari et al. } 2016\end{array}$ & $\begin{array}{l}\text { PMB80 (fHbp A22) } \\
\text { PMB2001 (fHbp A56) } \\
\text { PMB2948 (fHbp B24) } \\
\text { PMB2707 (fHbp B44) }\end{array}$ & $\begin{array}{l}331 \text { Healthy } \\
\text { adolescents who } \\
\text { had completed } \\
\text { all DTaP and } \\
\text { IPV } \\
\text { immunisations } \\
(11-19 y)\end{array}$ & $\begin{array}{l}\mathbf{8 1} \%-\mathbf{1 0 0} \% \text { across } \mathbf{4} \text { strains }^{\mathbf{b}} \\
(0,2 \text { and } 6 \text { months })\end{array}$ \\
\hline
\end{tabular}

*Strains homologous or near-homologous to vaccine fHbp.

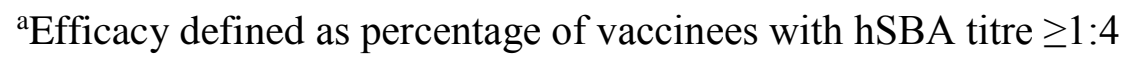

${ }^{\mathrm{b}}$ Efficacy defined as percentage of vaccinees with hSBA titre $\geq 1: 8$ (PMB2001, PMB2948, PMB2707) or $\geq 1: 16$ (PMB80) 
Table 3. A summary of key developmental clinical trials for 4CMenB.(Snape et al. 2010; Findlow et al. 2010; Kimura et al. 2011; Toneatto et al. 2011; Gossger et al. 2012; Vesikari et al. 2013)

\begin{tabular}{|c|c|c|}
\hline Study & $\begin{array}{l}\text { Number of } \\
\text { participants } \\
\text { (Age) }\end{array}$ & $\begin{array}{l}\text { Strain specific efficacy* of } \mathbf{4 C M e n B} \mathbf{B}^{\mathrm{a}, \mathrm{b}} \\
\text { (Dosing schedule) }\end{array}$ \\
\hline $\begin{array}{l}\text { Phase II randomised } \\
\text { controlled trial } \\
\text { (United Kingdom) } \\
\text { J. Findlow et al. } 2010\end{array}$ & $\begin{array}{l}135 \text { healthy infants } \\
\text { ( } 2 \text { months) }\end{array}$ & 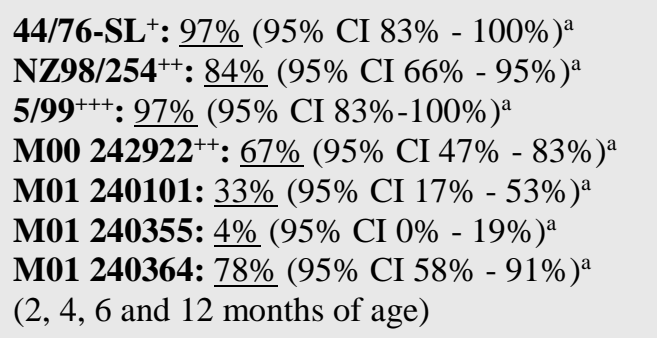 \\
\hline $\begin{array}{l}\text { Phase II randomised } \\
\text { comparative trial } \\
\text { (United Kingdom) } \\
\text { M. Snape et al. } 2010\end{array}$ & $\begin{array}{l}\mathbf{6 0} \text { healthy infants } \\
\text { (6- } 8 \text { months) }\end{array}$ & 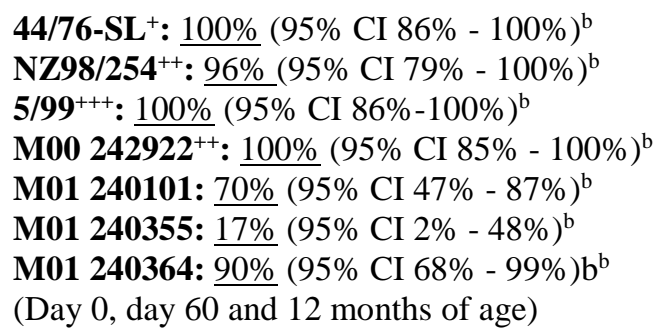 \\
\hline $\begin{array}{l}\text { Phase II open label trial } \\
\text { (Italy and Germany) } \\
\text { A. Kimura et al. } 2011\end{array}$ & $\begin{array}{l}\mathbf{5 4} \text { healthy adults } \\
\text { (18 - } 50 \text { years) }\end{array}$ & $\begin{array}{l}\text { 44/76-SL }{ }^{+}: \underline{97 \%}(95 \% \text { CI } 87 \%-100 \%)^{\mathrm{b}} \\
\text { NZ98/254 }^{++}: \underline{92} \%(95 \% \text { CI } 79 \%-98 \%)^{\mathrm{b}} \\
\text { 5/999+++ } 100 \%(95 \% \text { CI } 91 \%-100 \%)^{\mathrm{b}} \\
\text { (Day 0, day } 60 \text { and } 4 \text { months) }\end{array}$ \\
\hline $\begin{array}{l}\text { Phase I randomised } \\
\text { comparative trial } \\
\text { (United States) } \\
\text { D. Toneatto et al. } 2011\end{array}$ & $\begin{array}{l}70 \text { healthy adults } \\
\text { (18 - } 40 \text { years) }\end{array}$ & 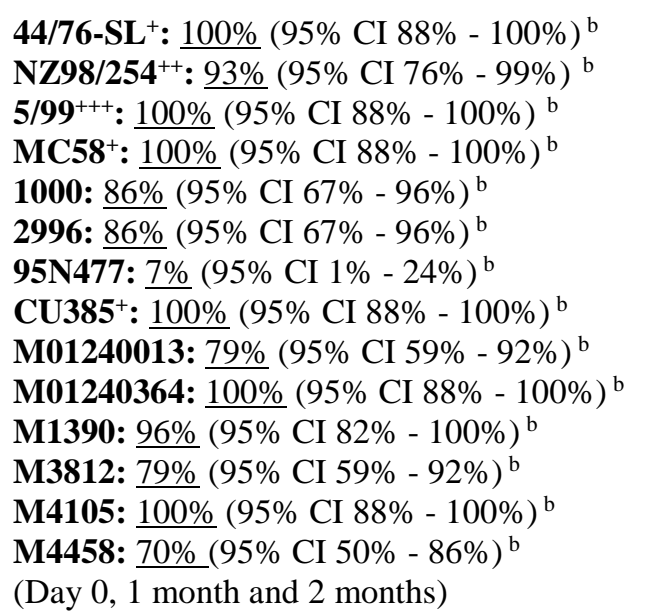 \\
\hline $\begin{array}{l}\text { Phase IIb randomised } \\
\text { controlled trial } \\
\text { (Belgium, United Kingdom, } \\
\text { Czech Republic, Germany, } \\
\text { Italy and Spain) } \\
\text { N. Gossger et al. } 2012\end{array}$ & $\begin{array}{l}1885 \text { healthy infants } \\
\text { ( } 2 \text { months) }\end{array}$ & $\begin{array}{l}\text { 44/76-SL }{ }^{+}: \text {99\% }(95 \% \text { CI } 97 \%-99 \%)^{\mathrm{b}} \\
\text { NZ98/254 }^{++}: \underline{79 \%}(95 \% \text { CI } 75 \%-82 \%)^{\mathrm{b}} \\
\mathbf{5 / 9 9} \mathbf{9 9}^{++}: \underline{99 \%}(95 \% \text { CI } 97 \%-99 \%)^{\mathrm{b}} \\
(2,4 \text { and } 6 \text { months of age })\end{array}$ \\
\hline $\begin{array}{l}\text { Phase III randomised } \\
\text { controlled trial } \\
\text { (Finland, Czech Republic, } \\
\text { Germany, Austria and Italy) } \\
\text { T. Vesikari et al. } 2013\end{array}$ & $\begin{array}{l}1555 \text { healthy infants } \\
\text { ( } 2 \text { months) }\end{array}$ & $\begin{array}{l}\text { 44/76-SL }{ }^{+}: \underline{81}^{\mathrm{a}} \\
\text { NZ98/254 }{ }^{++}: 22 \%^{\mathrm{a}} \\
\mathbf{5 / 9 9}{ }^{++}: \underline{99 \%^{\mathrm{a}}} \\
\text { M10713: } \underline{61 \%^{\mathrm{a}}} \\
(2,4,6 \text { and } 12 \text { months of age })\end{array}$ \\
\hline
\end{tabular}


${ }^{+}$Strains homologous to vaccine fHbp.

${ }^{++}$Strains homologous to vaccine PorA

${ }^{+++}$Strains homologous to vaccine NadA

${ }^{*}$ Efficacy defined as percentage of vaccinees with hSBA titre $\geq 1: 4$

${ }^{\text {a }}$ Efficacy at 1 month after $4^{\text {th }}$ (booster) dose

${ }^{\mathrm{b}}$ Efficacy at 1 month after $3^{\text {rd }}$ dose 


\section{Figure legends}

Figure 1. Structure of the $N$. meningitidis outer membrane and detergent extracted vesicles.

Outer membrane vesicles are produced by encapsulated Gram-negative bacteria, during normal liquid culture, as blebs directly from the outer membrane. A detergent extraction process improves yield and removes the majority of the endotoxic lipopolysaccharide, as well as other detergent soluble outer membrane constituents, though residual levels of these proteins remain. The level of each residual protein in different dOMVs may vary depending on detergent solubility and the protein density of the membrane portion from which the dOMV is derived. PorA is the immunodominant antigen on dOMV vaccines (Williams et al. 2007).

Figure 2. A schematic representation of the components in $4 \mathrm{CMenB}$.

The vaccine contains three soluble recombinant protein antigens, fHbp (as a fusion protein with genome-derived neisserial antigen 2091), NHBA (as a fusion protein with genomederived neisserial antigen 1030) and NadA. The fourth component is PorA as part of a dOMV derived from the New Zealand MenB strain NZ98/254. N,C: N- and C-terminus of fusion proteins (Giuliani et al. 2006).

Figure 3. Key events leading to the routine $4 \mathrm{CMenB}$ infant programme in the United Kingdom.

A timeline detailing important events between notification of the Joint Committee on Vaccination and Immunisation (JCVI), regarding 4CMenB approaching market authorisation, and the official announcement of the routine 4CMenB infant programme (JCVI 2014; Public Health England 2015).

Figure 4. Vaccine coverage and effectiveness of $4 \mathrm{CmenB}$ in the United Kingdom. (A) Average immunisation coverage for routine (borne between July-December 2015) and catch-up cohorts (borne in May or June 2015). Infants born in May were only eligible for a single 4CMenB dose at 4 months. (B) Laboratory confirmed group B IMD cases (between September 2015 and June 2016) and the vaccination status of each group. (C) Estimated vaccine effectiveness based on data between September 2015 and June 2016 (Parikh et al. 2016).

Figure 5. A simplified illustration of the theoretical effects of 4CMenB on carriage of invasive MenB strains.

Adolescent vaccination may reduce the carriage acquisition of invasive strains, corresponding to vaccine antigens, which make up only a small subset of the entire population of MenB carried. Therefore, the overall impact in the total carried population may be small and difficult to discern from carriage studies. Extremely large sample sizes and the ability to detect the low frequency target strains will likely be required to assess the vaccine's effect on carriage of invasive MenB (Read et al. 2014). 
Figure 1.
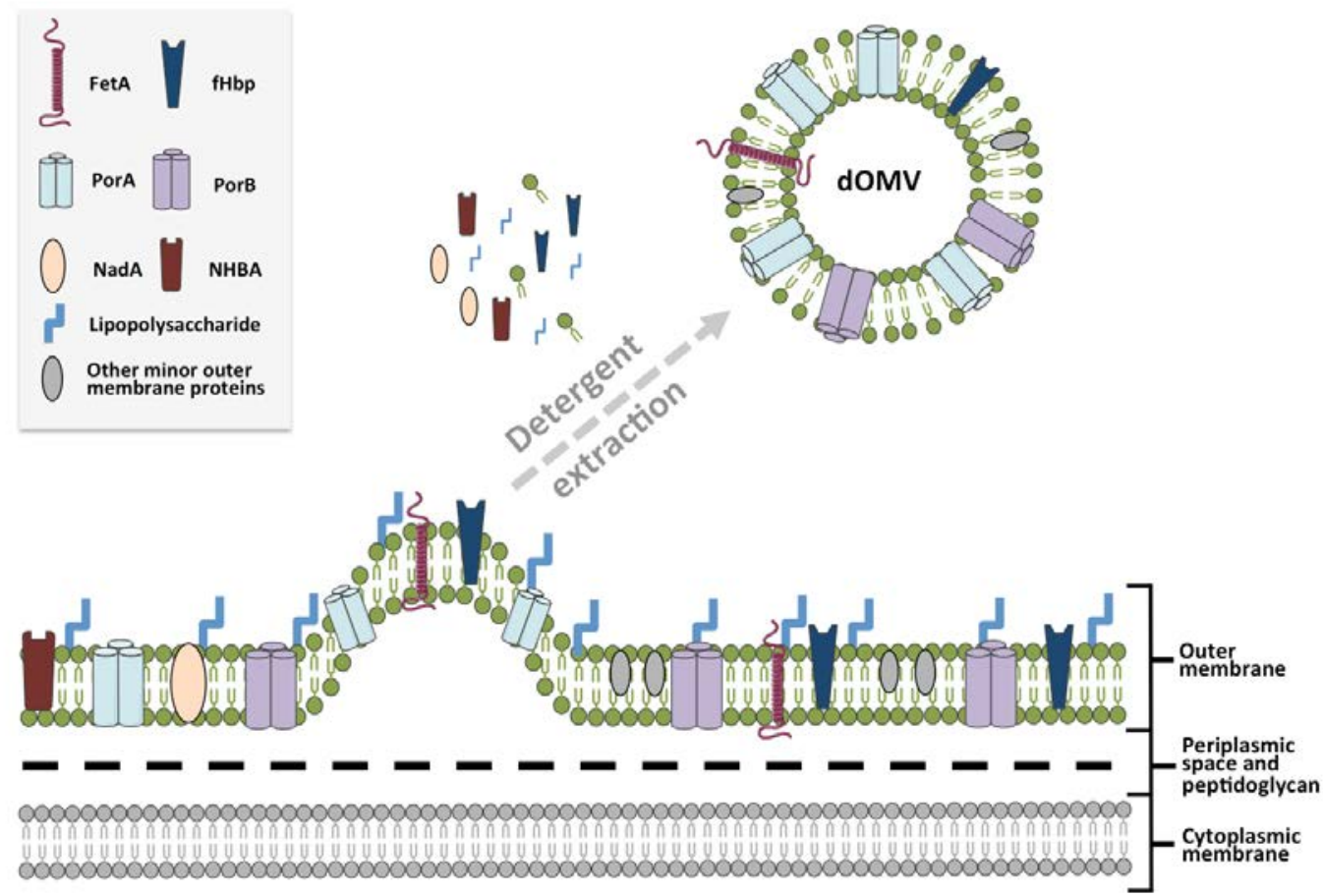

Figure 2.
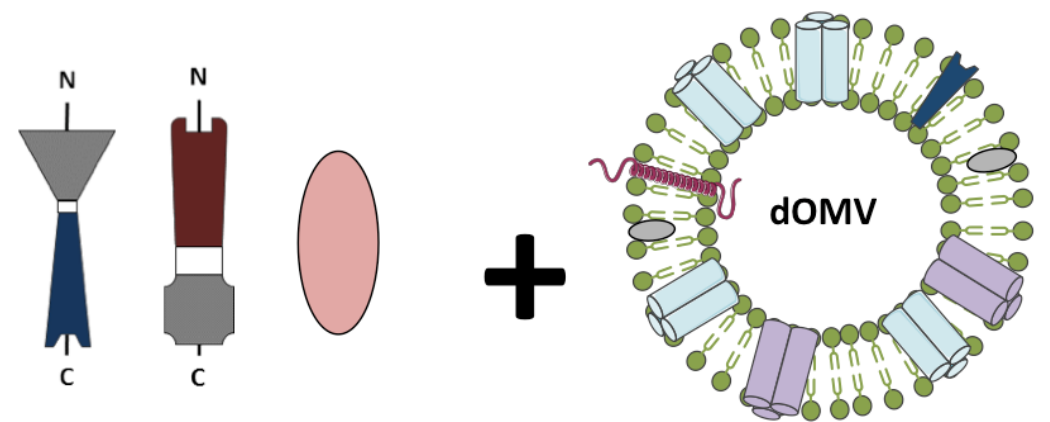

\section{Recombinant} protein antigens

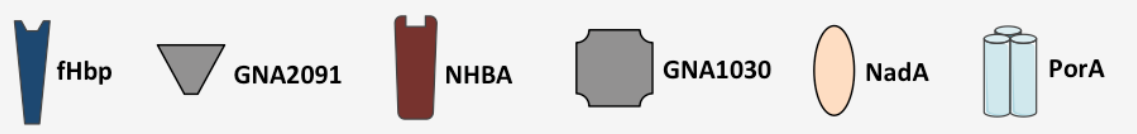


Figure 3.

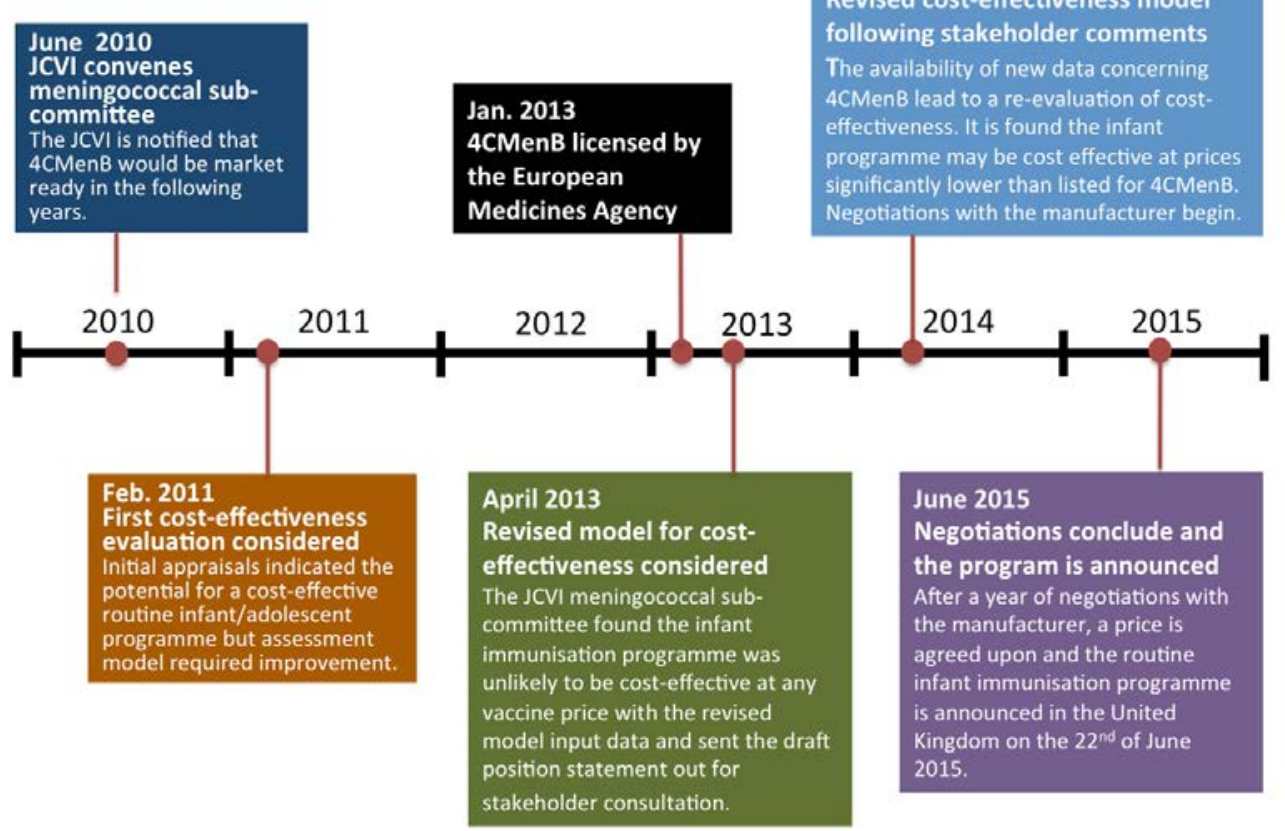

Figure 4.

\section{A}

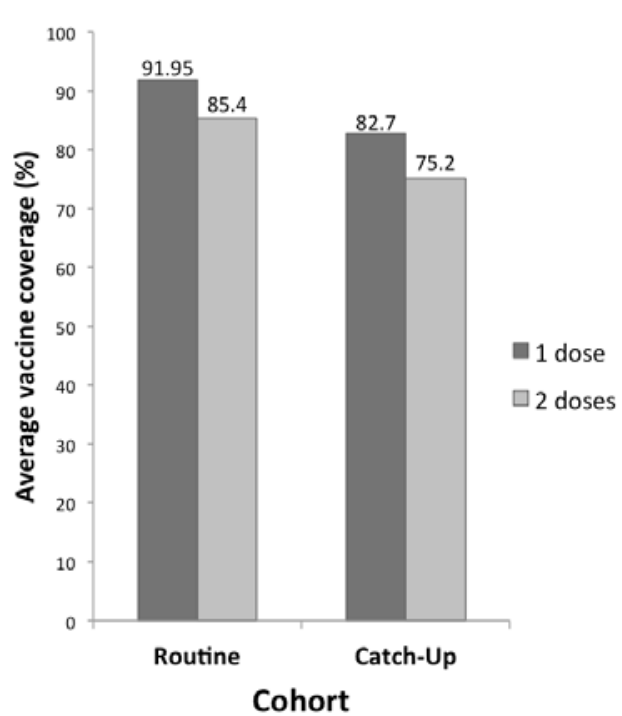

B

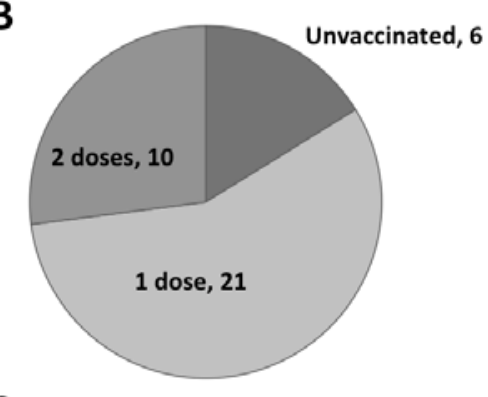

C

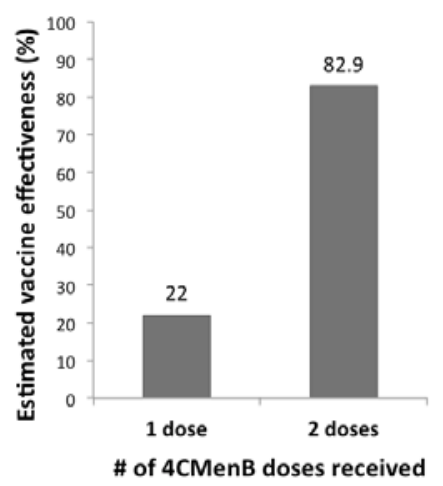


Figure 5.

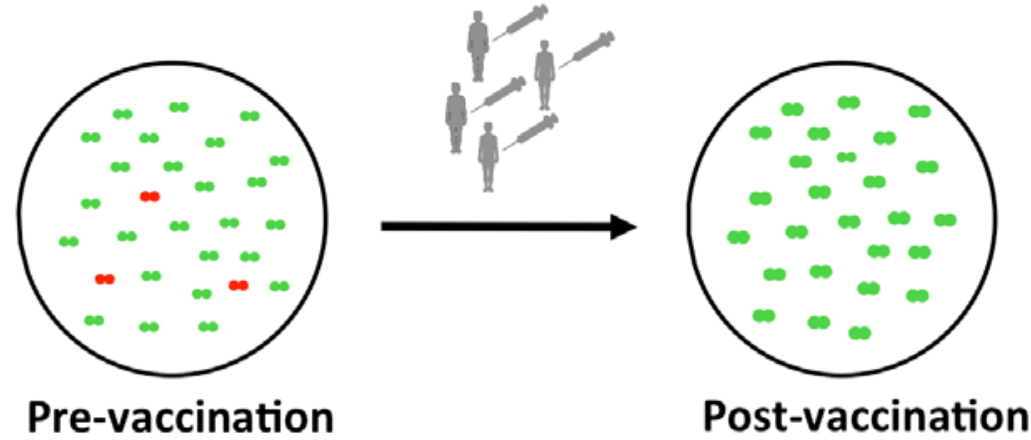

$\bigcirc_{\text {sample }}^{\text {Nasopharyngeal }}$ 